\title{
La oleada anti-gitana del siglo XVII
}

\author{
María-Helena Sánchez Ortega *
}

LAS PROTESTAS DE LOS REPRESENTANTES EN LAS CORTES

Las demostraciones de animosidad contra los gitanos, de lo que ya aparece algún ejemplo en el siglo XVI, llegan a su punto culminante en el siglo XVII. Las quejas de las Cortes y los memorialistas se desatan agriamente contra la minoría con reiterada monotonía. Se les acusa de llevar a cabo toda serie de desmanes, se pone en tela de juicio su conversión al Cristianismo, e incluso hay algún autor que les considera culpables de canibalismo. El siglo xVII es, sin duda, el período durante el cual la minoría gitana vivió en la península con mayores dificultades, tratando todavia de incorporarse de alguna manera a una sociedad en la que no encontraban acomodo, y desde mi punto de vista, el eco de estas dificultades llega hasta nosotros en los memoriales y las quejas de los representantes en Cortes, según veremos a continuación.

Desde los primeros momentos de la subida al trono de Felipe III, los representantes en Cortes empiezan a dirigirse a él para hacerle constar sus quejas por la presencia de los gitanos en el país. El 12 de abril de 1603 se le presentó un memorial explicando sus «excesos» y pidiendo al rey que se agravaran las penas contra ellos. Otro memorial se hizo el 7 de julio del mismo año y en él se expresaba la idea de que los gitanos no constituían un grupo étnico original -opinión que luego veremos aparecer en algunas pragmáticas - y bastantes escritores de memoriales:

* Profesora titular de Historia Moderna. UNED. 
"No habiendo resultado el remedio que se esperaba de las leyes que se han promulgado, en que se prohibe no vivan ni hablen como gitanos los que falsamente dicen serlo, como los que lo son, sin ninguna conveniencia al bien y utilidad pública, viviendo aún no sujetos a las leyes naturales, de donde nace cometer feisimos incestos, robos y latrocinios, siendo gentes vagamundas y sin entero conocimiento de la ley cristiana...» ${ }^{1}$.

Los representantes en Cortes terminan solicitando que se les expulse del reino, única medida que, a su modo de ver, puede solucionar el problema que inquieta a los campesinos:

«porque demás de quitar este abuso de gitanos, muchos que se valen del nombre para ejecutar sus malas inclinaciones se abstendrán del por no dejar su natural, y así será menor el número de desterrados" ${ }^{2}$.

A pesar de la dureza con que se expresaban los autores del memorial, el 12 de agosto de 1607 vuelve a dirigirse al rey el representante de Segovia y Guadalajara, don Alonso de Ulloa, exponiendo en esta ocasión nuevas razones que venían a sumarse a las aducidas en el caso anterior:

\begin{abstract}
"Cuán notorios son los delitos y hurtos que hacen los gitanos en estos reinos que ordinariamente resultan en gente pobre y siempre andan juntos cuatreros que les compran las cabalgaduras que hurtan a los labradores y a otras personas que demás de perder su caudal, les imposibilita a poder cultivar las tierras por no tener con que comprar otras cabalgaduras, y asi no pueden acudir a sus labores" ${ }^{3}$.
\end{abstract}

El 13 de febrero de 1609 nuevamente vuelven a exponerse al rey las razones que los representantes en Cortes encuentran contra los gitanos repitiendo con insistencia que sus hurtos de ganado afectan fundamentalmente a la gente pobre, y a los labradores:

"porque por ser gente que ni las crian ni compran traen a las ferias mucha cantidad de cabalgaduras mayores y menores hurtadas, $y$ hay remitidas pagas de los hurtos que se hacen de unos puertos a otros adonde las pasan, y de esto resulta gran daño a los labradores por traer las labranzas quebradas y habiendo de traer muchas sustentán-

\footnotetext{
1 Actas de las Cortes de Castilla. Madrid 1877-1939, 53 vols. (t. 21, pág. 482).

2 Ibidem.

${ }^{3}$ Actas de las Cortes de Castilla, t. 23, pág. 320.
} 
dolas en el campo, no traen más de dos por la mucha costa de haberles de dar de comer en casa a la mano y dejan de tener yeguas para la labranza y crianza que es lo principal, para beneficiar y coger un pan, y otras cabalgaduras muy útiles y necesarias para el servicio de sus labranzas» ${ }^{4}$.

En consecuencia con estas opiniones, el representante Alonso de Ulloa vuelve a dirigirse al rey, en esta ocasión para proponer alguna medida que pueda suponer una solución para los males de los campesinos. Según Ulloa, se les debería señalar lugares para residir sin salir de ellos, y obligarles a que aprendieran algún oficio. Respecto a su conducta moral, las justicias y obispos deberían vigilar si estaban casados, recibían los sacramentos y bautizaban a sus hijos. También se les debería prohibir que usaran cabalgaduras, considerando las que tuvieran como robadas en el caso que llegaran a tenerlas.

Durante el año 1610 las quejas de las Cortes continúan apremiando al Rey para que disponga nuevas medidas que sirvan para contener a los gitanos. El 3 y el 8 de noviembre se le dirigen diversas peticiones solicitando que se les expulse del reino, bajo pena de muerte, y que no hablen su lengua, ni usen sus trajes, obligándoseles a vivir de su trabajo en el campo sin que puedan salir de los lugares donde se asentaren, insistiendo en que no deben tener cabalgaduras ni ir a ferias ${ }^{5}$. Los representantes reiteran su opinión acerca de sus malas costumbres y su ausencia de actitudes cristianas. La exposición que hacen también en estas fechas los representantes describen un estado de cosas que coincide en lo esencial con el informe de las justicias y corregidores de 1628 que veremos a continuación:

«Ha venido la vida licenciosa de esta genta a tanta rotura que andan compañias enteras de hombres y mujeres, todos con armas y escopetas, y llegan a los lugares y les dan lo que piden por excusar sus violencias, y cuando se tiene noticia de ellos y se quiere hacer alguna prevención para castigarlos, son gente tan astuta y montaraz que jamás se puede dar con ellos y cuando se da se resisten y han hecho muchas muertes, y luego dejan las mujeres y ellos huyen porque son tan sueltos que nadie puede seguirlos ${ }^{6}$.

${ }^{4}$ Actas..., t. 25, págs. 68-69.

${ }^{5}$ Actas..., t. 26, pág. 163.

${ }^{6}$ Actas..., t. 26, pág. 163. 
Con la misma fecha de 8 de noviembre aparecen en las actas de Cortes nuevas y alarmantes noticias acerca de la situación:

\begin{abstract}
«El reino dice que son grandes y lastimosas las quejas que cada dia vienen a él de los daños, robos, hurtos y salteamientos que hacen los gitanos y gitanas, tienen perdida gran parte de la labranza y crianza de estos reinos, porque como sus hurtos son cabalgaduras, y roban tantas, los miserables labradores al primero que les hacen quedan perdidos, sin sustancia ni hacienda para poder comprar otras, obligándolos a encerrarlas de noche y no poderlas dejar en los pastos y no tienen con qué sustentarlas en sus casas, y así se les mueren de hambre, los ganaderos y pastores que van a trabajar a los extremos y suben a las sierras, como es forzoso llevar sus pobres atillos en pollinos, andan tras ellos como lobos, y se les hurtan y les obligan a ir cargados sin poder sufrirlo, a cuya causa mueren muchos y quedan sus ganados solos, lejos de sus tierras" ${ }^{7}$.
\end{abstract}

Según vemos, las circunstancias descritas por los representantes en Cortes no podían dejar al monarca insensible, a pesar de lo cual, el 24 de diciembre de 1610 vuelve a aparecer una nueva solicitud respecto al problema de los gitanos. Los representantes aseguran que se trata de "una de las cosas más dignas de remedio que al presente se ofrecen en estos reinos" y piden que se les expulse del país en un breve plazo de tiempo, imponiendo la pena de muerte a aquellos que regresen.

"Los que se quisieren quedar sea avecindándose en lugares, villas y ciudades de estos reinos que sean de mil vecinos arriba y no pudiendo usa el traje, lengua y nombre de gitanos ni gitanas pues no lo son por nación, quede perpetuamente este nombre y uso confundido y olvidado..." ${ }^{8}$.

Se sugiere también que se les prohiba llevar a cabo tratos de ganados mayores o menores $u$ otras cosas semejantes bajo pena de muerte.

\footnotetext{
7 Ibidem.

${ }^{8}$ Ibidem.
} 
Las peticiones para expulsar a la minoría se repiten en varias ocasiones más durante estas fechas ${ }^{9}$, sin duda al calor de la expulsión de los moriscos que Felipe III ordena durante estas mismas fechas, y los gitanos atraviesan, desde mi punto de vista, por uno de los momentos en que la amenaza estuvo más cerca de cumplirse.

La expulsión de los moriscos entre 1609 y $1610^{10}$ convulsionó al país por razones tanto económicas como sociales. Según señalan Domínguez Ortiz y Vincent la orden fue incumbencia directa de Felipe III y se fundamentó principalmente en la seguridad del Estado, aunque también se mencionan razones de carácter religioso. Los moriscos contaron con el apoyo de un numeroso grupo de nobles que señalaron al virrey de Valencia la ruina económica que les amenazaba si la expulsión se llevaba a efecto, y desató una gran polémica incluso entre los contemporáneos, que contemplaban los perjuicios económicos que podía acarrerar, pero el rey permaneció inflexible y el bando partidario de la expulsión consiguió imponer su criterio. Los moriscos de Valencia, Castilla, Extremadura y Aragón abandonaron el país en fechas sucesivas ocasionando un grave perjuicio en la economía del país en general, y a la de algunos nobles en particular. Parecía, por tanto, inevitable que se expulsara a continuación a una minoría mucho más reducida en número y bastante menos productiva, como la gitana. Sorprendentemente, sin embargo, los gitanos tuvieron mejor suerte que los productivos y pacíficos moriscos, probablemente a causa de la propia convulsión que originó la laboriosa expulsión de los moriscos.

A pesar de las presiones de las Cortes, y por las razones a que acabo de aludir, Felipe III se limitó a dictar una nueva pragmática contra la minoría el 15 de octubre de $1611^{11}$. La expulsión de los moriscos

\footnotetext{
${ }^{9}$ Actas..., t. 26, págs. 291-24. Dic. 1610; t. 27, pág. 378. Cortes de Madrid de 1611 a 1612, t. 28, pág. 240. Cortes de 9 de febrero de 1615, Memorial de 9 de abril de 1615; $t$. 28, pág. 201, peticiones de abril de 1615; t. 32, pág. 118. Cortes de Madrid de 1617 a 1620. Petición de 30 de julio de 1618; t. 34, pág. 325. Cortes de 1617 a 1620, t. 40, pág. 309. Cortes de 14 de febrero de 1623 a 18 de febrero de 1624 . Petición de 26 de enero de 1624.

10 La pragmática en que se decretó la expulsión de los moriscos se promulgó el 9 de diciembre de 1609 (Novísima Recopilación de las Leyes de España mandada formar por SM Carlos IV, ed. facsímil BOE, lib. 8, ley 25, tit. 2), pero su aplicación fue larga y complicada y se prolongó hasta 1610. La bibliografía sobre esta cuestión es muy amplia, pero debe consultarse principalmente: el libro de Dominguez ORTIZ, Antonio y VINCENT, Bernard., Historia de los moriscos. Vida y tragedia de una minoría. Madrid, Rev. de Occidente, 1978, 313 páginas. B. Vincent y $\mathrm{A}$. Domínguez dan una cifra de 300.000 expulsados.

${ }^{11}$ Novisima Recopilación de las Leyes de España acordada formar por SM Carlos IV, ed. citada.
} 
estaba todavía demasiado próxima para que el país se embarcara de nuevo en una aventura similar. La pragmática no presentaba grandes novedades, y se contentaba con volver a pedir a los gitanos que se ocupasen en oficios, especificando en esta ocasión que el trabajo debía ser la labranza de la tierra y no otros, bajo las mismas penas que se les habían señalado anteriormente.

Como es lógico, las quejas de las Cortes que venian pidiendo disposiciones más tajantes desde hacia tiempo, no cesaron con estas disposiciones, y de nuevo vuelven a alzarse voces contra el grupo en 1615 y 1618. Se suplicaba al rey que se ocupara a la mayor brevedad del problema, mandando expulsarles del pais y obligándoles a avecindarse en lugares de mil vecinos, prohibiéndoles usar el traje, la lengua, llevar a cabo compras y ventas de ganado, etc. Las Cortes de 1617-1620 repiten la petición y, finalmente, Felipe III vuelve a dictar una nueva pragmática.

De acuerdo con esta nueva ley, de 28 de junio de $1619^{12}$ se alude a los motivos que han originado las nuevas normas y se recogen las aspiraciones de las Cortes:

\begin{abstract}
«En las cortes que se celebraron esta villa de Madrid el año pasado de 1619 entre otras cosas nos presentaron los Procuradores dellas, los grandes daños que resultan a estos nuestros Reinos por las muertes, robos y hurtos que hacen los gitanos que andan vagando por el Reino, proponiéndonos los medios que se ofrecían para remediar los dichos inconvenientes y daños y porque en todo deseamos el mayor alivio de nuestros súbditos y vasallos y que en ello se ponga el remedio debido. Ordenamos y mandamos que todos los gitanos que al presente se hallaren en estos nuestros Reinos salgan dellos dentro de 6 meses que se han de contar desde el día de la publicación desta ley y que no vuelvan a ellos so pena de muerte, y que los que quisieren quedar sea avecindándose en ciudades, villas, y lugares destos nuestros Reinos de 1.000 arriba y que no puedan usar del traje, nombre y lengua de gitanos y gitanas, sino pues no lo son de nación, quede perpetuamente este nombre y uso confundido y olvidado".
\end{abstract}

Se les prohíbe también que traten en compras y ventas de ganados mayores o menores bajo la misma pena, y se ordena a todas las justicias del Reino que se ocupen de hacer guardar y ejecutar lo contenido en la

12. Novísima Recopilación..., tit. XVI, ley 4. ${ }^{\text {a }}$; AHN, Consejos, libro 1531; Consejos. Sala de Alcaldes de Casa y Corte, lib. 1208, fol. 47. 
ley. Según vemos, Felipe III siguió en realidad una política coherente respecto a la minoría, ordenando finalmente su expulsión en términos inequívocos. La diferencia fundamental que puede señalarse respecto a la actitud de la Corona en el caso de los gitanos consistió, desde mi punto de vista, en que la expulsión de los moriscos se llevó a cabo de forma perentoria y organizada, mientras que en esta ocasión se encomendaba simplemente a las justicias el cumplimiento de la ley, tal vez por considerarse que el número de los gitanos no era lo suficientemente importante como para volver a movilizar la maquinaria burocrática y represiva que consiguió la eliminación de los moriscos. Por otra parte, es probable que pareciera más conveniente encargar su expulsión a las justicias del reino, teniendo en cuenta que se les concedía permiso para permanecer en lugares de más de 1.000 vecinos siempre que se ocuparan en los trabajos del campo. Vistas así las cosas es probable que la promulgación de la ley haciendo responsables a las justicias pareciera una medida suficiente. Una medida, que al igual que en los casos precedentes, resultaba utópica y prácticamente imposible de aplicar.

\section{LAS QUEJAS DE LOS MEMORIALISTAS}

La promulgación de la Pragmática de 1619, a pesar de las reiteradas instancias por parte de las Cortes que la habian precedido, estuvo muy lejos de dar una solución definitiva al problema de los gitanos. El 26 de enero de 1624 vuelve a elevarse la voz de los representantes del Reino reiterando que no se han solucionado «los grandes e intolerables daños que causan los gitanos, pues la experiencia enseña que su habitación y modo de vivir se compone de robos e insultos, no dejando los ganados seguros y cuando llegan a las ferias venden los que han hurtado o los truecan».

Los procuradores en Cortes no eran, por otra parte, los únicos en presentar al rey su opinión contraria a la minoría, según veremos a continuación, y a lo largo del siglo XVII las acusaciones se repiten una y otra vez por parte de canónigos, licenciados y expertos en leyes. Los memoriales dirigidos al rey en que se ponderan los perjuicios que los grupos de gitanos vagabundos causan al país se convierten en uno de los lugares comunes más repetidos por los hombres de letras que se ocuparán durante el período de los males del reino y su posible solución. 
La conciencia que se despertó entre los contemporáneos de la decadencia española desde fines del siglo XVI y durante el siglo XVII dio lugar a la aparición de una serie de escritores empeñados en buscar las causas de la crisis y su posible solución. Son los llamados «arbitristas" que escribieron memoriales o libros acerca de la cuestión más o menos acertados. La crisis era tan evidente después de 1600 que la Corte queda inundada de informes de juristas, quejas de las corporaciones o memoriales redactados incluso por los párrocos. Los aspectos fundamentales que preocupaban a estos hombres eran la despoblación y la ruina del país, que cada cual atribuía a una causa distinta, la decadencia de la ganadería trashumante, la ruina de las ciudades, y la industria etc. Los nombres de los memorialistas más notables son de sobra conocidos, y no es momento de entrar ahora en esta cuestión. Las soluciones que proponen son muy diversas, y comprenden tanto reformas económicas como políticas o sociales. Los problemas de fondo, sin embargo, son comunes y entre ellos se plantea con frecuencia el peso muerto que representaba para la economía del país la existencia de un numeroso grupo de personas ociosas y sin ocupación que pululaban por las ciudades.

El aumento de población que experimentó Castilla durante el siglo XVI dio lugar también a un núcleo de marginados compuesto por hombres y mujeres muy heterogéneos: pobres, pícaros, buhoneros, pretendientes de empleo, ex-combatientes, elementos del hampa e incluso extianjeros. Los miembros de esta sociedad acudían a las grandes ciudades desde las villas y parroquias más pobres con la esperanza de disfrutar de las limosnas que repartían abundantemente las iglesias y monasterios o los propios ciudadanos obligados a ello por el espíritu religioso de la época. Las descripciones que hacen los contemporáneos de ciudades como Toledo, Sevilla, Valladolid, y, especialmente, Madrid no dejan lugar a dudas. La cuestión preocupó con frecuencia a los arbitristas, quienes no dejaron de señalar el perjuicio que representaba para el país la nube de mendigos y personas holgazanas que pululaban por las calles de las ciudades más importantes. Uno de los autores que escribieron en contra de los gitanos, Fernández de Navarrete ${ }^{13}$, resumía así el problema en su Conservación de Monarquías:

13 J.l. GutiérRez Nieto llevó a cabo un extenso estudio sobre el tema del arbitrismo que sirve para completar algunos aspectos de esta cuestión en los que no resulta posible extenderse aquí (Historia de España, fundada por MENÉNDEz PIDAL, R., dir. por JoveR, J.M. «El siglo del Quijote (1580-1680). Madrid, Espasa Calpe, 1986, t. XXVI; «El pensamiento económico, político y social de los arbitristas", pags. 235-351. FERNÁNDEZ DE NAVARRETE, 
«Despuéblase asimismo Castilla, por el poco cuidado y vigilancia que se tiene en castigar vagamundos y holgazanes, de que es infinito el número en estos reynos, siendo esta la causa de haber tantos pobres. .....(los extranjeros) pasan por los campos fértiles de España, y los ven cubiertos de hortigas y esponas, por no haber quien los cultive; habiéndose los mas de los españoles reducido a la holgazanería, unos a título de nobles, otros con capa de mendigos. $Y$ es cosa digna de reparar el ver que todas las calles de Madrid están llenas de holgazanes y vagamundos, jugando todo el dia a los naypes aguardando la hora de ir a comer a los conventos, y las de salir a robar las casas; y lo que peor es, el ver que no solo siguen esta holgazana vida los hombres, sino que están llenas las plazas de pícaras holgazanas, que con sus vicios inficionan la corte, y con su contagio llenan los hospitales; y las que justamente se quitaron de las casas públicas, están expuestas en las calles y plazas, y muy ordinariamente en las gradas de las iglesias; cosa tan indecente como digna de remedio" ${ }^{14}$.

La imagen recogida por Fernández de Navarrete coincide, por otra parte, con los testimonios de carácter literario divulgados por la novela picaresca. El ambiente que rodea a muchos protagonistas de Cervantes, o el propio patio de Monipodio debió ser fácil de observar en ciudades como Sevilla, o Toledo, plagadas de pordioseros, gentes del hampa, y extranjeros pedigüeños, gentes, por lo general, que escapaban muchas veces al brazo de las justicias por incopetencia o venalidad. Según un memorial del siglo XVII, la situación de Sevilla era tan lamentable como la de la propia Corte:

"Seis años ha que no he visto ahorcar en Sevilla ladrón, ni tal se probara habiendo enjambres de ellos como de ovejas, lo que más en Sevilla hay son forzantes, amancebados, testigos falsos, rufianes, asesinos, logreros, regatones, vagabundos que viven del milagro de Mahoma, sólo de lo que juegan y roban en las casas de bilhan y en los tablados de dados, pues pasan de trescientas casas de juego y tres mil de rameras, $y$ hay hombres que con dos mesas quebradas y seis sillas

\footnotetext{
Pedro, «Conservación de Monarquías y discursos políticos sobre la gran consulta que el Consejo hizo al señor Rey don Felipe III, dedicada al Presidente y Consejo Supremo de Castilla por el Ldo...» Madrid, Biblioteca Nacional.

${ }^{14}$ Las casas públicas de prostitución o mancebías fueron toleradas en España hasta que Felipe IV las prohibió según la pragmática de 4 de febrero de 1623, y de forma más radical en la pragmática de 1 de enero de 1632. El 11 de julio de 1661 mandó de nuevo que se las detuviera y condujera a la cárcel.
} 
viejas les vale cada año la coyma ocho mil ducados, pues ya la mercancía y el trato se han convertido en robo y en ragatonería" ${ }^{15}$.

El fenómeno de la pobreza organizada no era, por otra parte, exclusivamente español. El vagabundeo se había convertido en un problema importante en toda Europa ya desde el siglo xv, y ciudades como Roma, París, no presentaban un aspecto muy diferente al de las españolas. Aunque resulta dificil señalar los factores concretos que provocaron esta situación, es evidente que durante el siglo XVI y XVII se produjo un deterioro profundo de la situación de las clases trabajadoras que debió incidir, sin duda alguna, en este estado de $\operatorname{cosas}^{16}$. El aumento demográfico es también un factor a tener en cuenta, lo que unido a la enorme movilidad de estas gentes que buscaban un trabajo o un cobijo fácil dan al problema características internacionales. La dirección seguida en muchas ocasiones por estos trabajadores estacionales, y por muchos mendigos era la del área mediterránea, lo que contribuyó a agravar el problema de las ciudades españolas. Hombres, mujeres y niños procedentes de Francia, Irlanda o Alemania llegan hasta Castilla con la esperanza de encontrar algún remedio. En muchas ocasiones se ocupaban en los oficios más bajos, pero generalmente se veían obligados a caer en la mendicidad o a fingir algún engaño para acudir a la sopa de los conventos. Según Domínguez Ortiz ${ }^{17}$ los peregrinos a Santiago de Compostela formaban verdaderas masas en las que se mezclaba la religiosidad, y el simple vagabundeo.

Los arbitristas y autores de memoriales se quejan también de estos emigrantes que vienen a aumentar la población marginal del país, y el tono que utilizan en sus protestas resulta muy similar, con frecuencia, al

15 Citado por Domínguez Ortiz, Antonio, en Orto y Ocaso de Sevilla (Memorial del Ldo. Porras de la Cámara al Arzobispo de Sevilla, 1525), publicado por PAZ, A., Revista de Archivos, Tomo V, pág. 550-554.

Resultan seriamente interesantes también las monografías de MARAVALL, J.A. La novela picaresca desde la perspectiva histórica y social. Siglos XVI XVII. Madrid, Taurus, 1986, y GEREMEK, B. La estirpe de Caín. La imagen de los vagabundos y de los pobres en las literaturas europeas de los siglos XV al XVII. Madrid, 1990.

${ }^{16}$ Sobre el fenómeno de la mendicidad a escala europea puede consultarse una numerosa bibliografia, o la síntesis hecha por KAMEN, $H$., en el capítuio correspondiente de su libro El siglo de Hierro. Madrid, Alianza Editorial, 1983 ( «La voz de los desposeídos").

17 Dominguez Ortiz, A. Los extranjeros en la vida económica de la España del siglo xvil. Madrid 1960, pág. 48. 
que veremos a continuación contra los gitanos ${ }^{18}$. En la Consulta de 1618 con motivo de la Junta Reformación, Fernández de Navarrete, autor al que aludiré a continuación en relación con la población gitana, se quejaba del gran número de irlandeses que habían venido a España, sin que ninguno se hubiera aplicado «a las artes o al trabajo de la labranza ni en ninguna otra aplicación más que mendigar siendo gravamen y carga de la República» ${ }^{19}$.

También a principios del siglo XVII otro autor al que veremos ocuparse del problema gitano, Pérez del Barrio, se quejaba del enorme número de extranjeros que habían venido a España -50.000 aseguraba este autor- que sólo se dedicaban a mendigar a pesar de ser jóvenes:

\begin{abstract}
«A la golosina de la abundancia de España se han venido más de 50.000 hombre y mujeres estrangeras, genta moza y fuerte, que pudo llevar el trabajo de muy largo camino, andan mendigando y multiplicando hijos y pobreza, con vida libre, y viciosa, sin que ninguno quiera usar oficio que en su tierra se sujetava; alla aborrecian la ociosidad que por bia siguen, pues se ven por las calles exercitos de holgazanes y pobres fingidos, mugeres mozas, carhadas de muchachos, que todos pudieran servir y la justicia los dexa en su libertad, tan licenciosa que en las iglesias inquietan y ofenden la devoción; por las calles estorvan, y en las casas no nos podemos descuydar con ellos. Tengo por cierto que el buen govierrio no se atreve a nombrar comisarios que los ajusten en la vida y obliguen al trabajo, o a que salgan del Reyno, porque no suzeda lo que a los Juezes de los gitanos dizen que les quitaron lo que tenían y les dexaron a que comenzaran a hurtar de nuevo...” ${ }^{20}$.
\end{abstract}

Según vemos, los contemporáneos juzgaron con rigor el problema de los mendigos falsos o fingidos, incapaces de distinguir entre la población emigrante y necesitada, los pícaros, y los auténticos mendigos. Las consecuencias de las crisis o del aumento de población se atribuían en muchas ocasiones a las propias víctimas de las circunstancias y, en con-

\footnotetext{
18 Fernández Navarrete, P., dice en la Consulta de 1618 a propósito de los irlandeses: «son muchos los que han venido a España sin que en tanto número se halle que se haya aplicado a las artes o al trabajo de la labranza ni en ninguna otra aplicación más que a mendigar, siendo gravamen y carga de la República» (ob. cit., cap. VII) (citado por VIÑAs MEY, C., "Notas sobre la asistencia social en España", Anales de la Real Academia de Ciencias Morales y Políticas, núm. 24, 1971, págs. 177 a 215.

19 FERNÁNDEZ NAVARRETE, P. ob. cit.

20 Pérez del Barrio, Gabriel, "Secretario y Consejero de señores y ministros», Madrid 1667 (Biblioteca Nacional).
} 
secuencia, la opinión pública no resultaba muy favorable a estos grupos marginales, a pesar de que por estas mismas fechas empieza a organizarse la beneficencia ${ }^{21}$.

Resultaba, por tanto, inevitable, que durante estas mismas fechas se registrara un aumento de la animosidad hacia los gitanos. Los arbitristas y autores de memoriales - una de las manifestaciones de la opinión pública durante el periodo, según señala Kamen ${ }^{22}$ - dirigen también su atención hacia la situación de la minoria gitana, en términos no muy elogiosos. Las opiniones de los hombres del siglo xVII se dirigen también contra los hombres y mujeres gitanos, y de nuevo se pide contra ellos la expulsión, o el rigor en la aplicación de las penas.

Uno de los primeros estudiosos que se sintió inclinado a incluir la minoría gitana en el conjunto de males que aquejaban a España en esta etapa de crisis y dificultades fue Sancho de Moncada. En tanto que catedrático de la Universidad de Toledo, escritor sobre materias económicas y hombre conocedor de la política de su época, Moncada emprende un análisis de lo que hoy llamaríamos la situación socio-económica del país. En los nueve discursos que componen su Restauración política de España ${ }^{23}$, que publicó en 1619 , Moncada analiza las causas de la mala situación interior de la Monarquía, y lleva a cabo en pocas páginas, un tratado de teoría política y pedagogía real, según lo considera Jean Vilar. El año de la publicación de la Restauración en España se vivían las consecuencias de la crisis política que había llevado a la caída del valido Lerma. El análisis de Moncada en, cualquiera que sea el juicio que merezca a los economistas, refleja el desasosiego del país ante la subida al trono de Felipe III y las nuevas tendencias de la sociedad española. La situación era tan grave que el propio rey había encargado en 1618 un informe al Consejo de Castilla para conocer la causa de la decadencia interior y la forma de ponerlos remedio. La comisión presentó su respuesta casi al mismo tiempo que aparecía el libro de Moncada, el 1 de

${ }^{21}$ Sobre la beneficencia en España hay una bibliografia interesante. Puede verse también el artículo de VINAS MEY, G., antes citado.

22 Kamen, H., señala en España 1469-1714. Una sociedad conflictiva, Madrid, Alianza Universidad, que los numerosos escritos dirigidos por los arbitristas o los autores de memoriales constituían «la medida de la madurez política de España, que a principios del siglo XVi contaba con una opinión pública reconocible y con un gobierno que estaba dispuesto a tolerar la diversidad de opiniones".

${ }^{23}$ Moncada, Sancho de, Restauración política de España. Edición a cargo de Jean Vilar. Presentación de Enrique Fuentes Quintana. Madrid, Instituto de Estudios Fiscales, 1974. 
febrero de 1619, lo que demuestra el grado de conciencia que existía acerca de la gravedad del momento.

Los Discursos de Moncada son, por tanto, la obra de un catedrático que contempla la realidad económica y social de un país en busca de alguna solución. Según Moncada, los males de España provienen de tres males fundamentales: demográfico, monetario y hacendístico. A lo largo de sus discursos describe y analiza las causas de la decadencia del país, entre las que se encuentran la caída demográfica, -Discurso Segundola crisis monetaria - Discurso Tercero-, para lo que Moncada propone medidas útiles, o arbitrios, tales como restaurar el comercio y la producción nacional de lo que se ocupa en el mismo Tercer Discurso -así como el saneamiento, reforma, y consolidación de la Hacienda- lo que le ocupan del Cuarto al Sexto libro. Para completar su visión crítica de la España de su tiempo, Moncada revisa de nuevo los aspectos más llamativos de la situación, a través de los nueve "daños" de que se ocupa en el Discurso Séptimo: daño de la agricultura, "trajes demasiados", importancia de las alcabalas, cobradores y ejecutores, gente en la Corte, rigor en la ejecución de las leyes, y abundancia de religiosos, El Discurso contra los gitanos que viene a continuación, y que no estaba incluido en su primer proyecto, puede considerarse como el análisis particular que el autor lleva a cabo de uno de estos «daños». Moncada se suma aquí, de alguna manera, al coro de voces que piden la desaparición de los grupos ociosos, problema agudo de los siglos XVI y XVII e incluso XVIII, según vimos al principio.

En su Discurso contra los gitanos, primero cronológicamente de este estilo, aunque no la primera voz que se levanta la voz contra ellos en el periodo, puesto que es preciso considerar las quejas de las Cortes, Moncada establece los puntos fundamentales por lo que van a transcurrir los razonamientos de todos los que vuelvan a escribir sobre el tema: origen y naturaleza de los gitanos, daños que causan al país, leyes que se han dictado contra ellos, medidas que se deben adoptar al respecto. A pesar de ser uno de los más breves de esta serie, o precisamente por eso, el Discurso de Moncada fija las características del tema durante toda una centuria, y establece un importante precedente que a continuación será tenido en cuenta por casi todos los estudiosos que se ocupen de la decadencia del país.

Moncada comienza, según queda dicho, haciendo un breve resumen histórico de la llegada a Europa de la minoría, cuya penetración establece en 1417, aunque no pueda dar ninguna opinión concreta acerca de su origen, sobre el que discrepan todos los autores que han escrito sobre el tema, según dice. Moncada, sin embargo, piensa que los que están en 
España no tienen nada que ver con los auténticos, con lo que da forma a una idea que ya hemos visto aparecer entre las opiniones expresadas por los representantes en Cortes y que ahora cristaliza de forma definitiva gracias a la concisión de pensamiento y estilo que caracterizan a Moncada:

"La segunda y la cierta opinión es que los que andan en España no son Gitanos, sino enjambres de zánganos y hombres ateos y sin ley ni religión alguna, Españoles que han introducido esta vida o secta del Gitanismo, y que admiten a ella cada día la gente ociosa y rematada de España» ${ }^{24}$.

Moncada pasa a continuación a exponer los daños causados por los gitanos, en un apartado que titula, elocuentemente: "los gitanos son muy perniciosos a España». Según el teólogo, todas las naciones les tienen por "dañosísimos", en primer lugar porque son "espías y traidores a la Corona» en especial porque "entran con facilidad en tierras de enemigos y saben las lenguas de todos", y en segundo lugar por su ociosidad, que Moncada describe tajantemente:

"Lo segundo porque son gente ociosa, vagabunda, y inútil a los Reinos sin comercio, ocupación, ni oficio alguno; y si alguno tienen es hacer ganzuas y garavatos para su profesión, siendo zánganos que sólo viven de chupar y talar los reinos, sustentándose del sudor de los míseros labradores...

Mucho más inútiles que los Moriscos, pues estos servían en algo a la República, y a las rentas Reales, pero los Gitanos no son labradores, hortelanos, oficiales ni mercaderes y sólo sirven de lo que los lobos, de robar y huir» ${ }^{25}$.

La opinión que tiene Moncada de las mujeres gitanas es todavía más radical y negativa. Las acusa de ser "públicas rameras", que causan graves daños con «bailes, ademanes, palabras, y cantares torpes». Por su causa se han perdido doncellas y mujeres casadas se han apartado de sus maridos.

24 Moncada, S., Ob. cit, pág. 213.

25 Moncada, S., Ob. cit,, pág. 214. 
En cuanto a los hombres, son «ladrones famosos» que han cometido por todas partes, llegando incluso a querer asaltar Logroño. Están especializados en los robos de ganado y con ellos causan grandes daños a los campesinos a los que, además, engañan, en los tratos.

Por último, Moncada señala que son «encantadores, adivinos, magos, quirománticos, que dicen por las rayas de las manos lo futuro que ellos llaman buenaventura, y generalmente son dados a toda superstición» ${ }^{26}$.

Moncada pasa a continuación a exponer las penas que han merecido los miembros del grupo, como hacerles cautivos y condenarles a muerte, que considera muy justas ${ }^{27}$ y pasa a recomendar la expulsión en lo que señala que hay coincidencia entre los diversos autores que se han ocupado del asunto:

«Todos los doctores que resuelven lo dicho en el capítulo 4 que los
Gitanos se podían condenar a muerte, tendrían por piedad de $V$. Majes-
tad que los desterrase perpetuamente de España, y por justísimo. Mu-
chos y doctos no sólo tienen por justo el expelerlos, sino que no acaban
de admirarse de que se consientan en Repúblicas Cristianas, y aún
juzgan por afrenta de los Reinos que los sufran. ... La razón es la que
obliga a mirar por el bien de los súbditos (...) y los daños que de los
Gitanos reciben los de $V$. Majestad propuse a $V$. Majestad en el capítulo
2 , siendo punto de gran consideración que los que causaban los moris-
cos movieron el pecho real y piadoso de $V$. Majestad a expelerlos aun-
que eran muchos, y habían de hacer falta a la población, al comercio, y
rentas Reales, a los oficios y agricultura. Y siendo los Gitanos pocos, y
totalmente inútiles para todo parece más preciso expelerlos, siendo tan-
tos los daños que hacen. Lo segundo, porque los Gitanos, como he
dicho, son Españoles que (como otros profesan religiosos santas) estos
profesan con el Gitanismo robar, y los demás vicios dichos en el capí-
tulo 2 . Y siendo justo desterrar del Reino a los que han cometido algún

${ }^{26}$ Moncada, S., Ob. cit., pág. 216. Sobre la cuestión de las artes mágicas de los gitanos y su situación religiosa ya me ocupé monográficamente en mi estudio. La Inquisición y los gitanos. Madrid, Taurus, 1988.

${ }_{27}$ Los aspectos legislativos a los que alude Sancho de Moncada son los siguientes:

Los gitanos se deben prender en donde se hallaren. «El derecho civil dispone que sin remisión alguna sean presos los vagantes dondequiera que se hallaren..."

Los gitanos se debian condenar a muerte. «Por espías y traidores a la Corona, como ladrones, cuatreros o abigeatos, cuarto como encantadores y adivinos y otras artes que usan prohibidas bajo pena de muerte. Por último, en tanto que herejes».

Los gitanos por leyes de España son expelidos de ella, cap. $V$ «En primer lugar, en tanto que mendigos sanos, y segundo como rameras públicas: En tercer lugar como gente que escandido y que ve el ojo que daña las costumbres y honestidad". 
delito grave, lo será mucho desterrar a los que profesan ser dañosos a todos. Lo tercero, porque todos los Gobernadores de acierto han procurado siempre sacar de su Reino a los ociosos y valdíos... ${ }^{28}$.

Moncada señala que la medida de obligarles a vivir en poblaciones grandes ha resultado abiertamente insuficiente y que resulta, por tanto, más conveniente expulsarles, sin deternerse a sentir compasión por las mujeres y los niños, como se hizo con los moriscos. El Discurso concluye con una breve exposición a propósito de medidas similares con los grupos ociosos y con los propios gitanos que con el criterio erudito de su época adereza con ejemplos tomados de la Biblia y la tradición clásica.

El Memorial de Salazar de Mendoza ${ }^{29}$ contra los gitanos, tan directo y sencillo como el de Sancho de Moncada, comienza con un breve preámbulo en el que nuestro sacerdote justifica su petición al rey con un resumen de los daños que atribuye al grupo. Al igual que Sancho de Moncada, hace notar que el mismo año en que él ha redactado su argumentación, 1618, ha habido tropas de hasta 800 individuos robando, y "cometiendo otros enormes insultos» entre las tierras de Aragón y Castilla. También han llevado a cabo otros desmanes, como desnudar a un ermitaño que iba de Navalagamella a Valdemorillo, y mataron a un hombre entre Galapagar y la Torre y le cortaron la cabeza: No ha sido, por tanto, posible reducirles a pesar de que se trata de una minoría mucho más peligrosa que la de los Moriscos, aspecto que, como vemos, interesa subrayar a todos los contemporáneos de la expulsión:

«Nunca se oyó, supo, ni entendió, de los Moriscos semejante atrevimiento. A muchos les parece son mas prejudiciales y dañosos estos que aquellos. Más inútiles y desaprovechados, claro está que lo son. Porque, señor, los Moriscos cultivaban la tierra, entretenían el comercio, las artes y oficios mecánicos. Los Gitanos no salen al campo, sino es para robar y matar. Los oficios que deprendieron, y exercitan, son hurtos y engaños. Aquellos por miedo de la pena acudian a las iglesias, oyan Misa, confessavan y trahían algunas siapensaciones para casamientos. Estos no saben que cosa es la yglesia, ni entran en ella, sino a cometer sacrilegios» ${ }^{30}$.

${ }^{28}$ MONCADA, S., Ob. cit., pág. 225.

29 Salazar de Mendoza, Pedro, "Compendio de lo mas substancial que escrive el doctor Salazar de Mendoza en los cuatro libros de la Monarchia de España. Memorial de gitanos". Madrid, Biblioteca Nacional.

${ }^{30}$ Salazar de Mendoza, Pedro, Ob. cit. 
Al igual que los demás autores que se ocupan del tema, Salazar Mendoza tiene una opinión sumamente negativa acerca de la situación religiosa de la minoría. No sólo opina que no visitan las iglesias, sino que tampoco reciben sacramentos, contraen matrimonios sin dispensas e incluso pone en duda que estén bautizados:

«Bien que los Moriscos eran Apóstatas, por estar baptizados. De los Gitanos no se yo quien sepa que lo están, aunque ellos dixen que si, hazen contra si en dezillo. Porque en Berberia viven como Mahometanos: con los Turcos son Turcos, hereges con los hereges, acomodándose con todas las naciones. En lo que ser traydores a V.M. como lo fueron los Moriscos, como entran y salen con tanta facilidad, y llaneza en las tierras de infieles, muy verisimil es que son o pueden ser espias: $y$ asi se puede pensar de su mala inclinación" ${ }^{31}$.

Los gitanos, por tanto, son según Salazar Mendoza, un grupo indeseable que ha sido expulsado de diversos paises por sus malas costumbres, lo que le permite a nuestro sacerdote repetir un paralelismo en el que insisten todos los autores del reinado de Felipe III: la relación entre moriscos y gitanos en la que los segundos quedan todavía peor parados que los primeros:

«De manera que entre Moriscos y Gitanos, comoruin ganado, ay poco que escoger. Puedese dar entre los unos y los otros un Paralelo como los de Plutarco. Si alguna diferencia ay entre ellos, y si ventaja se llevan, los Gitanos la hazen a los Moriscos. Porque estos nunca llevaron tras si a los Christianos para sus ruindades, y malas costumbres, antes se recatavan de ellos. Los Gitanos se han llevado muchos holgaçanes, y vagamundos, para vivir a sus anchuras. Porque cosa muy sabida es que muchos de los que andan con los Gitanos, assi hombres, como mugeres, son Españoles, y 10 mesmo passa en otras provincias" ${ }^{32}$.

Para completar la descripción de las "maldades" del grupo, Salazar les acusa de robar niños pequeños, y engañar a las doncellas y a las casadas con sus «hechizerias y embelecos», entre los que se cuentan

\footnotetext{
31 Salazar de Mendoza, P., Ob. cit.

32 Salazar de Mendoza, P., Ob. cit.
} 
las propias habilidades para la danza y la escena, punto en el que no insisten los demás autores.

«Siempre hallan enredos y traças para delinquir, especialmente con unas danças en los días festivos, quando está la gente más devota, y mas descuydada. Allí se fingen Apóstoles, aculla Reyes Magos, en otras partes los siete Infantes de Lara. Todo para divertir, y entretener, mientras hazen los hurtos. Porque acude la gente a vellos, dexando las casas abiertas y aunque las dexe cerradas, y entoncen las roban los que no son de Mascara. Enterneceria mucho a V.M. la aflicción de sus pueblos. Porque al punto que entran Gitanos en ellos, como son ladrones y facinerosos públicos. Todo el cuydado es guarda el hijo, esconder la hija, velar la casa, y recoger sus aves y ganados...»

Pocas novedades aparecen a continuación, en el «Memorial de gitanos" propiamente dicho. Lo mismo que Sancho de Moncada, Salazar Mendoza cree oportuno hacer un resumen histórico acerca de los lugares en que se les conoce y de su posible origen. Recoge también todos los datos eruditos divulgados hasta entonces por autores renacentistas como Sebastián Munster y Aldo Manucio -cuestión sobre la que no resulta posible extenderse en estas páginas - sin descartar la tradición difundida por los propios gitanos en el momento de su aparición en la península a propósito de su procedencia y peregrinación penitencial. También en esta segunda parte vuelve a insistir en sus "malas costumbres", al detenerse a recoger algunos datos a propósito de su organización social:

\begin{abstract}
«No son mejores en España que en Alemania, Francia o Italia, ni en otras regiones. Ya diximos que unos se llaman Grecianos, y otros Egipcianos. Los unos y los otros tienen de costumbre andar divididos por familias; y tienen sus cabeças a quien Ilaman Condes, escogiendo para este ministerio al más brioso y de mas valor, y mas conveniente para governallos. A el acuden con sus diferencias, si bien estén de asiento en lugares donde ay justicias. Estos Condes embian los varones Gitanos a que hurten de noche y las mugeres de dia; y los toman quenta, y reparten lo que han hurtado. Acuden a las ferias a recoger los hurtos, a trocallos, $y$ vendellos» ${ }^{33}$.
\end{abstract}

Para Salazar Mendoza, lo mismo que para la mayoría de los autores

33 Salazar Mendoza, P., Ob. cit. 
que se ocuparon de la minoría en estos memoriales, las mujeres gittanas resultan todavía más peligrosas y aborrecibles que sus compañeros masculinos:

«Porque las mugeres andan de puerta en puerta diziendo la buenaventura; entran y salen en las casas, y tientan a todos con sus embaycaciones, so color de pedilles limosna».

Salazar Mendoza señala también la costumbre del grupo para elegir compañera, lo que parece estar relacionado, desde su punto de vista, con la suspicacia que despierten respecto a la propiedad ajena:

«La mejor información que hazen para casarse, es de la muger mas diestra y astuta en hurtar, y engañar, sin reparar en que sea parienta o casada. Porque nohanmenester más que juntarse con ella y dezir que es su muger. Algunas vezes, la compran a sus maridos, o las reciben empeñadas" ${ }^{34}$.

Los gitanos, en una palabra, son un grupo especializado en robos y engaños para Salazar Mendoza, quien los describe de nuevo en este sentido en un tono que recuerda de cerca las palabras de Cervantes que deberemos tener en cuenta en un capítulo próximo:

«Viven sin ley divina, ni humana. Tienen mucha viveza en saberse librar de las manos de la justicia. En naciendoles el hijo, se enseñan a hurtar, de dia y de noche, en el campo, y en poblado Como y de qué manera han de hechar la culpa, si fueren cogidos con elhurto en las manos; y que la hechen a persona que no puede ser condenada a galeras.

Usan de apeles falsos para andar vagamundos, tan bárbaros son, que con poca atención se conocen. Aposéntase en cuevas o casas viejas derribadas, fuera de las ciudades, villas o lugares donde llegan. Para encarecer mucho en España las astucias y cautelas de un hombre, le dizen, que es un Gitano; a las roncerias, y raposerias, Ilaman Gitanerías. Son innumerables los daños y males que en España han causado con sus malas artes, y embustes, assi generales como particulares. En tiempo de pestilencia intentaron saquear la ciudad de Logroño, y en otras partes han hecho grandes desafueros. En Aranda de Duero, y en otros muchos lugares, han sido menester muchas vezes juntarse gente

${ }^{34}$ Salazar Mendoza, P., Ob. cit. 
armada para resitillos, y hechallos de sus términos. Como deziamos, ninguno ay en España que no aya participado de alguna de sus detestables faciones. En tal lugar fingieron una procesión de disciplina el Jueves santo, y porque la yglesia era pequeña, la hizieron despejar hasta de los vancos, para que cupiesse mas gente, so color de que en tal dia hadie havia de estar sentado. Acudió todo el lugar, viéndola desocupada. La processión fue roballos a todos los vezinos. No mientras passava, porque no passo. En otro ofrecieron una comedia a la tarde, en la plaça. Adereçose muy bien y previnieron plata para las apariencias. Dizen que les falta un Danzarin, que vendría al amanecer. Quedan todos los adereços en la plaça, y lievánselos media noche» ${ }^{35}$.

Después de esta contundente exposición, Salazar Mendoza recurre a la exposición de las pragmáticas emitidas contra la minoría, con lo que concluye su discurso.

Más duro, probablemente, que el memorial de Sancho de Mocada, es todavía el escrito que dirigió al rey Juan de Quiñones en 1631, reinando ya Felipe IV.

A pesar de que, según veremos a continuación, pronto desaparecerá el decreto de expulsión en contra de la minoría, todavía se seguirá pidiendo que se les haga salir del país a lo largo de todo el siglo XVII, y uno de los más encarnizados partidarios esta solución lo fue el autor al que acabo de referirme, hasta el punto de que en su «Discurso contra los gitanos» ${ }^{35}$ pretende fundamentalmente convencer al monarca de la conveniencia de esta medida.

Juan de Quiñones era alcalde de Casa y Corte, es decir acostumbrado a ocuparse de asuntos cotidianos de la justicia, y había tenido que vérselas en diversas ocasiones con hombres y mujeres gitanos en el ejercicio de su profesión., y este trato con los miembros menos afortunados de la minoría era el que había inducido a Juan de Quiñones a sus radicales puntos de vista. Al parecer, la motivación para su «Discurso» partió de un suceso relacionado con un grupo de gitanos en el que tuvo que ver nuestro alcalde. Un correo que procedía de Flandes había sido asaltado en tierras de Sepúlveda, rompiéndose las valijas con los pliegos en busca de dinero o alhajas. Quiñones se ocupó del caso, prendió a los responsables - de los que dice que también habían llevado a cabo otros hurtos- y mandó ahorcar a cinco gitanos, cuyos cuartos se expusieron

${ }^{35}$ Quiñones, Juan de, "Al Rey nuestro Señor, el doctor d. Juan de Quiñones. Alcalde de Casa y corte. Discurso contra los gitanos». Madrid, MDCXXI (Madrid. Biblioteca Nacional). 
en el camino real donde habían cometido el delito. Cuatro fueron azotados y condenados a galeras perpetuas y las mujeres azotadas, y expulsadas del país, advirtiéndoles que se las condenaría a muerte si reincidian.

El hecho debió impresionar más que en otras ocasiones al alcalde, puesto que éste es el punto de partida para su escrito:

\begin{abstract}
«De las informaciones que hize, y de otras noticias que se me han dado he venido a entender que esta gente es perniciosa, mala, ociosa, vagante inutil, y sinprovecho para estos Reynos, y de mucho daño para los súbditos y vasallos. $Y$ assi me hallo obligado a representar (por el servicio de $V$. Magestad) lo que he sabido, y siento desta maldita canalla, y referir que género de gente son, de donde vinieron, que daños hazen, y como se remedirán, para que considerado, mande $V$. Magestad salgan destos Reynos, pues nada en ellos, sino hurtos y robos" ${ }^{36}$.
\end{abstract}

Según señala el propio Quiñones, el «Discurso» comienza indicando los diversos países donde se les conoce y los nombres con que se les designa Gitanos en Castilla, Cinganos o Cingaros en Italia, Bohemianos en Francia, Ciegeuner en Alemania. En todos estos lugares, asegura Quiñones, "professan malas y depravadas costumbres; viven sin conocimiento de Dios, y sin observancia de las leyes ${ }^{37}$.

Acerca de su origen, no parece posible, según nuestro autor, llegar a una conclusión, porque "unos dizen de unas Regiones, y otros de otras». Quiñones hace, sin embargo, un resumen de los autores conocidos al respecto y señala los países que se consideraban por estas fechas como posible patria del grupo. Quiñones resume también las ideas difundidas en Castilla a propósito de sti peregrinación, que parece indignar al experimentado alcalde.

"Todo esto es mentira, bellaquería, embustes y enredos de los que ellos dizen y hazen, porque llamallos Gitanos mas es porque los imitan en el torpe modo de vivir que por ser sus descendientes" ${ }^{38}$.

\footnotetext{
${ }^{36}$ QuIÑNeNeS, I., Ob. cit.

${ }^{37}$ QuiÑones, I., Ob. cit.

${ }^{38}$ QuiÑones, I., Ob. cit.
} 
Como vemos, Quiñones no es partidario, como otros muchos contemporáneos, de atribuirlos un carácter racial diferente al resto del país atribuyendo su origen a los hombres y mujeres marginados por la sociedad:

«Y assí esta vil canalla no es otra coxa que hombres y mugeres huidos por delitos, o deudas, gente amotinada y facinerosa, que no pudiendo estar en los lugares donde son conocidos, se retiran a los montes o lugares de ñoca vezindad, y escondidos para ocultarse. $Y$ el traer las caras quemadas, es por las injurias del tiempo, y andar ostigados del Sol».

Quiñones dedica a continuación su escrito a describir las costumbres de este grupo tan repudiable desde su punto de vista, tan escandalosas para la óptica de la época que con su descripción espera suscitar la indignación del monarca. A propósito del tono de su piel, sigue rechazando que se trate de un color natural, y sugiere, apoyándose en un autor precedente, que todos los meses se la tiñen con alguna hierba, lo que hacen con el objeto de engañar a propósito de su origen. Otro fraude sería también el traje y la lengua, con el fin de terminar la que llama "secta del gitanismo" a la que admiten a toda la "gente ociosa, perdida, y rematada, a quien con facilidad enseñan su idioma». Quiñones señala, sin embargo, que la llamada jerigonza es corrupción del término «Gyrgonça», lengua todavía ampliamente utilizada por todos ellos. Quiñones constata a este respecto.

«Es su modo de hablar, de que usan todos ellos, mugeres, y hijos, con que se entienden de manera que nadie los puede entender $"{ }^{39}$.

Respecto a la organización social de la minoría también tenía Quiñones algunas noticias que conviene recoger. Quiñones recuerda de nuevo a los "condes» y «duques" con que hicieron su aparición en la península los gitanos, y da cuenta al lector de que el grupo está dividido en «familias» y «tropas», a cuya cabeza se encuentra un lider que recibe este título. Quiñones añade:

\footnotetext{
${ }^{39}$ QUIÑONES, I., Ob. cit.
} 
«eligiendo para este título al más valiente, brioso, de mayores fuerças, más astuto, sagaz y conocimiento para governallos. Éste compone sus diferencias y pleitos, aunque residan en lugar donde aya justicia, y les ordena lo que han de hazer. Sale con ellos de noche a robar los ganados, y saltear en los caminos a los passajeros, por ser acomodada para sus hurtos; y lo que hurtan lo reparten entre ellos, acudiendo con la tercia parte a su Capitán, como si fuera juez de tercias partes" ${ }^{40}$.

El alcalde aprovecha aquí para hacer una digresión acerca de los desmanes que atribuye al grupo, y a continuación pasa a hacer acusaciones bastante graves que en el ambiente confesional del siglo XVII hubieran podido tener consecuencias bastante serias:

«No entienden que cosa es la Iglesia, ni entran en ella, sino es a hazer sacrilegios. No saben las oraciones. Yo los examiné a ellos y a ellas y no las sabían; y si algunas, no perfectamente. No se les administran los santos Sacramentos, y aunque casen con parientas no traen dispensaciones. No ay quien sepa si están bautizados" ${ }^{41}$.

Como vemos, la organización social y las costumbres sociales del grupo gitano resultaban para los españoles más chocantes e incomprensibles que las de los moriscos o los judíos al no contar con el respaldo de una religión suficientemente definida que sirviera de justificación para sus rasgos diferenciales, como en el caso de las minorías antes indicadas, aunque repudiadas por la jerarquía cristiana. Quiñones señala a continuación que pueden tener hasta tres mujeres, razón por la que procrean tantos hijos, y explica que siguen un sistema de repudios sucesivos cuando la primera esposa ha envejecido. A este propósito, cuenta la siguiente anécdota:

«El Licenciado Alonso Durán, Relator que ahora es de nuestra Sala, me ha dicho y certificado que el año de 623 o 624, un Simón Ramírez, Gitano, Capitán que era de un tropa dellos, repudió a Teresa su muger, porque era ya vieja, y se casó con una, que se dezia Melchora, que era moça, y hermosa y que el dia que se hizo el repudio, y celebraron las bodas, iva caminando y vió que debaxo de unos árboles, en el campo, que está en la jurisdicción de la villa de Delitosa, avia grande fiesta y

${ }^{40}$ QUIÑNONES, I., Ob. cit.

${ }^{41}$ QUINONES, I., Ob. cit. 
regozijo y preguntando la causa, le dixeron se casava Simón Ramírez con una Gitana y repudiava a otra, y que la repudiada le dixo llorando, que la dexava por vieja, y se casava con otra, porque era moças ${ }^{42}$.

Según otro testimonio citado también por Quiñones, unos miembros del grupo habían confesado que no se casaban, sino que elegían a sus mujeres en unos banquetes. Siguiendo con sus costumbres religiosas, el alcalde da cuenta de que no tienen tratos con los párrocos, ni cuentan con ellos para organizar sus matrimonios.

En otras palabras, Quiñones duda de que se trate de auténticos cristianos, lo que hace constar de forma explícita apoyándose en los autores anteriores:

«Muy graves Escritores los tienen por hereges y muchos por Gentiles, idólatras o Atheos, sin Religión alguna, aunque en la apariencia exterior se acomodan con la Religión o secta de la Provincia donde andan, siendo con los Turcos, Turcos; con los hereges, hereges, acomodándose en todas las naciones, y como entran y salen con tanta facilidad $y$ llaneza en las tierras de infieles, es muy verisimil que son o pueden ser espias; y así se puede sospechar de su mala inclinación. Tengolos por peores que a los Moriscos, porque aquellos professavan su secta. Estos no tienen ninguna, y asse aplican a todas. Aquellos cultivavan la tierra, para que diese frutos. Estos se comen los que no cultivan, siendo çanganos de la Republica, que no trabajan y comen. $Y$ si en algo se ocupan, es en hazer barrenas, por ser de especie de gançuas y aun por dissimular las muchas que entre las barrenas hazen» ${ }^{43}$.

Para completar el cuadro de «malas costumbres» de los gitanos, Quiñones termina aludiendo a otra acusación tradicional, la de que son adivinos y hechiceros que engañan a los ingenuos campesinos:

«Y porque no queden cortos, ni faltos en todo género de maldades, son también encantadores, adivinos, magos, y chiromáticos, que dizen por las rayas de las manos lo futuro, que ellos llaman buena ventura (y yo mal para quien la dizen, pues o le engañan o le roban). $Y$ generalmente son dados a toda superstición ${ }^{44}$.

42 QUIÑONES, I., Ob. cit.

43 QUIÑNONES, I., Ob. cit.

44 QuIÑONES, I., Ob. cit. 
Quiñones lamenta en este punto las «donzellas" que se han perdido con sus hechizos y las casadas que se han apartado de sus maridos, refutando con ideas basadas en el sentido común y en autores como Del Río el engaño de la Quiromancia.

Un aspecto que no conviene olvidar del escrito del alcalde de Casa y Corte son las atrocidades que atribuye a los miembros de la minoría. Basándose en parte en su propia experiencia, y en parte en los relatos recogidos de labios de otras personas que entraron en relación con hombres o mujeres de la minoría, Quiñones da cuenta al rey de los hechos que pueden servir para decidir su expulsión. Según Quiñones, intentaron saquear Logroño "en tiempos de pestilencia», y en Aranda de Duero y otros lugares fue necesario reunir a gente armada para resistirles y echarlos. Hacia el año 1618 -según el mismo autor- se habían movido tropas por Castilla y Aragón de más de 800 individuos que cometieron desmanes por la zona que el Consejo procuró remediar. Quiñones detalla algunos casos de otros alcaldes de Casa y Corte, y termina relatando algunas anécdotas que reflejan el temor casi supersticioso que podían infundir los miembros del grupo:

«Y el año passado de 629 dando tormento a quatro Gitanos don Martín Fajardo, juez que procedía contra ellos en Zaraicejo, confessaron aver muerto a un Fraile de la Orden de S. Francisco en el monte de las Gamas, jurisdicción de la ciudad de Truxillo, y que se le comieron. $Y$ también a una y a una peregrina. El alcalde de la villa del Montijo, le dixo al dicho don Martín Fajardo, que un vezino de alli, buscando en el campo una yegua que se le habia perdido, vió en el lugar de Arroyo el puerco, entrando en una casa caida a buscarla, a unos Gitanos, que estavan assando un quarto de persona humana. Dize también que un pastor de la ciudad de Guadix, yendo perdido por la serra de Gadol, vió una lumbre, y entendiendo que era de pastores, fué hazia ella, y halló una quadrilla de Gitanos que estavan assando la mitad de un hombre, y la otra mitad colgada de un alcornoque, y quando le vieron, le dixeron que se sentasse a la lumbre, que cenaría con ellos, y dezian entresi: Grosso está este; y fingiendo se quería echar a dormir, se arrojo la sierra abaxo, y se escapó de sus manos. En el puerto Ohanes, en Sierranevada, mataron también unos Gitanos a un muchacho, y se le comieron. No hazían mas los Caribes en las Indias, que comían carne humana» ${ }^{45}$.

${ }^{45}$ QUINNONES, I., Ob. cit. 
Quiñones completa su tremendo discurso haciendo un resumen de las pragmáticas y leyes dictadas contra la minoría, y termina resumiendo así su postura:

«No es mi intento, Señor, se les quite la vida, si bien los que no estubieren avenzindados, y que huvieren contravenido a la cédula Real del año de mil y seiscientos y diez y nueve, son dignos de muerte. Sino que pues son gente sin provecho, salgan destos Reynos, sin tener consideración que estén avezindados, pues como dixo Platon, los ociosos son semejantes a los çanganos con agijón, que en cualquiera ciudad que están, la perturban, como la flema o cólera al cuerpo" ${ }^{46}$.

Los discursos contra los gitanos de Sancho de Moncada, Salazar Mendoza, y Juan de Quiñones, como ya habrá observado el lector, tienen muchos puntos de contacto. Todos ellos escriben en tiempo de Felipe III y los tres son decididos partidarios de la expulsión de una minoría que dista mucho de ser bien acogida en un país en que ya hace doscientos años que se han instalado. El tono y la actitud de los tres autores cuyos memoriales acabo de pormenorizar utilizan un tono tan radical y adverso hacia nuestro grupo marginal que resultan sumamente chocantes para la sensibilidad actual, que tendería a rechazar en bloque todas las aseveraciones de los memorialistas a causa de su abierta xenofobia y un cierto tinte de racismo. A pesar de todo esto, resulta más conveniente, desde mi punto de vista, despojar de estos elementos los discursos de Sancho de Moncada, Salazar Mendoza y Quiñones para valorar mejor las noticias socio-antropológicas que puede haber en sus escritos a propósito de la minoría gitana.

Los escritos de estos tres primero memorialistas reúnen todas las ideas que ya habíamos visto desfilar en las diversas protestas de los representantes en Cortes, y vienen a cristalizar, de alguna manera, la imagen estereotipada que se tenía ya por estas fechas acerca del grupo gitano: origen, características, organización social, comportamiento femenino, «habilidades» y rechazo social en forma de legislación. Estos son los puntos esenciales en torno a los cuales giran los escritos de los tres autores anteriores, cuya pauta será seguida por todos sus seguidores. $\mathrm{Si}$ a los aspectos referidos añadimos el apartado de las «anécdotas» citadas por cada autor, aspecto en el que tampoco son totalmente originales, tendremos el esquema general de los discursos contra los gitanos del siglo XVII.

${ }^{46}$ QuIÑONes, I., Ob. cit. 
Como ya he señalado antes, en estos memoriales se encuentra, fundamentalmente, el cliché o estereotipo de las autoridades civiles -en otra ocasión habrá espacio para analizar el cliché de carácter literariorespecto a un grupo mal asimilado y mal comprendido. Tanto las quejas de las Cortes, como este tipo de escritos, son el eco del temor y la desconfianza con que se contemplaba a una minoria cuyas infracciones parecen innegables. El temor y el rechazo habian llegado, sin embargo, a desmesurar sus fechorías y andanzas, según se puede observar, desde mi punto de vista, en las anécdotas acerca de los actos de canibalismos cometidos por algunos de ellos. Probablemente Quiñones recogía también alguna voz común extendida entre los sencillos y espantados campesinos. La historieta a propósito del pastor extraviado en la montaña parece evocar algún encuentro en el que los propios gitanos hubieran decidido gastar una broma pesada al mozo aterrorizado por el inesperado encuentro.

Las afirmaciones de este tipo de Juan de Quiñones, aunque él no es el único autor en recogerlas, según veremos en otro momento, son totalmente inadmisibles, aparte de otras consideraciones. Desgraciadamente, no se puede decir lo mismo respecto a las anécdotas relacionadas con los hurtos de ganado y engaños en las ferias, pero es indudable que Moncada, Mendoza y Quiñones escribieron con la explícita intención de lograr la expulsión de la minoría, lo que evidentemente les empujaba a tratar de abultar al máximo las «malas acciones» de unos hombres y mujeres que querían ver desaparecer de la península. Las noticias acerca del origen de los gitanos, así como las que se relacionan con la legislación contra ellos y quejas de las Cortes, constituyen el aparato erudito en que se apoyan los autores, y apenas merecen otro comentario, pero no ocurre lo mismo con otros apartados de estos memoriales en los que aparecen datos acerca de la situación religiosa de la minoría, organización social, etc. que merecen ser analizados detalladamente.

Como hemos podido observar, los tres autores coinciden en seguir señalando la presencia de los "condes" bajo cuya dirección llevan a cabo los gitanos sus aventuras. Los tres autores coinciden también, de acuerdo con la tradición, en señalar que el grupo aumenta considerablemente gracias a la admisión de hombres y mujeres procedentes de los cristianos viejos españoles, que se ven obligados a apartarse de la sociedad por diversos motivos. Moncada, Salazar Mendoza y Quiñones asimismo con otros autores, como Cervantes lo que le permitió señalar a Caro Baroja que la minoría gitana de estas fechas parecía recordar tanto por la aceptación del liderazgo del más apto, como por el sistema de 
agregación que indica la aceptación de nuevos individuos, sistemas muy alejados de nuestras fronteras y de Europa ${ }^{47}$.

Los gitanos debían ser, por tanto, un grupo de carácter patriarcal, a cuya cabeza se encontraba un líder, elegido entre los varones más aptos, y en el que la preponderancia de los hombres era notoria en todos los órdenes de la vida. Las mujeres gitanas desempeñaban, como en la actualidad, funciones «subalternas», pero indispensables, tales como pedir limosna, recoger noticias sobre los campesinos y vecinos, y reunir fondos por medio de la astucia o con pequeños trabajos. Nuestros memorialistas las describen diciendo la buenaventura, engañando a las mujeres solteras y casadas, y dando pruebas de una gran habilidad y facilidad de movimientos, con lo que compensan de alguna manera, el sistema patriarcal en el que están sumergidas. La mujer gitana, de acuerdo con la descripción de todos los autores que se ocuparon del tema durante esta época, debía aceptar el repudio de su marido cuando llegaba a la edad avanzada, lo que nos aproxima de nuevo a una organización familiar muy alejada de las costumbres españolas de la época ${ }^{48}$ : la poligamia sucesiva, destinada por tanto, a ser mal aceptada y comprendida por los españoles del siglo XVII, tan decididos defensores de las reglas morales dictadas por el concilio de Trento.

La situación religiosa del grupo, distaba mucho por tanto, de ser homologable con la de los cristianos viejos, y esto explica, desde mi punto de vista, las frecuentes acusaciones de impiedad, e incluso ateísmo, que aparecen en los memoriales ${ }^{49}$. Los gitanos resultaban una minoría chocante y difícilmente comprensible, puesto que no se conocía, como en el caso de los moriscos, o de los judíos, el patrón religioso que dictaba estas diferencias, y los españoles de los siglos XVI y XVII les

47 Caro Baroja, Julio, «Los gitanos en cliché», en Temas castizos. Madrid, Istmo, 1980.

«... el grupo puede ampliarse, sin embargo, por raptos 0 abandonos de niños (como en el caso de La gitanilla misma) o por "agregaciones" de individuos, como la del fraile Maldonado o Pedro de Urdemalas".

${ }^{48}$ Cualquier unión al margen de las normas establecidas por el concilio de Trento resultaba sospechosa de herejía y era, por consiguiente, objeto de la persecución inquisitoria. Los gitanos, no obstante cayeron raras veces en las redes de estos jueces. A este respecto, puede consultarse mi estudio L.a Inquisición y los gitanos. Madrid, Taurus, 1987.

49 A pesar de estas acusaciones, tampoco fueron los gitanos objeto de persecución religiosa de forma específica - diferenciándose claramente a este respecto de las minorías judía o morisca- sino que siempre fueron procesados por el Santo Oficio por delitos similares a aquellos en que incurrieron los cristianos viejos. Es decir, los llamados «delitos menores" en su mayor parte: hechicería mayoritariamente, blasfemia, alguna que otra proposición deshoneta y casos aislados de bigamia o ilusión.

De nuevo me remito a mi trabajo antes citado La Inquisición y los gitanos... 
contemplaron, por todas las razones que acabamos de ver, con recelo y antipatía no disimulados. El conflicto, por consiguiente, no se limitaba a los enfrentamientos entre dos grupos sociales con distinto grado de riqueza y evolución social, sino que tenía fuertes componentes étnicos entre los que la lengua, la famosa jerigonza que todos los autores encuentran peligrosa y susceptible de ser vehículo de extraños manejos, jugó también un papel importante.

Los autores de memoriales, manuales político-religiosos y similares se siguen ocupando del tema de los gitanos durante el siglo XVII. La ociosidad del grupo, sus desmanes, y la necesidad de expulsarles del país siguen siendo los temas centrales de sus razonamientos, pero no los únicos. Según hemos visto, la situación religiosa del grupo provocaba también comentarios adversos, y por lo general, se ponía en tela de juicio su conversión al cristianismo y su fidelidad a los mandamientos de la Iglesia. Afortunadamente para los hombres y mujeres del grupo, la Inquisición nunca los consideró como una minoría disidente en este punto, cuestión que, indudablemente, hubiera podido llegar a revestir una gran gravedad. Por fortuna para los gitanos, los autores que se ocuparon de las prácticas religiosas de los gitanos tampoco plantearon el problema con el carácter radical con que lo presentó en 1647 el fraile Pedro de Figueroa en su Aviso de Príncipes ${ }^{50}$. Para Figueroa los gitanos eran auténticos "vasallos del demonio", y considera que su "vida desalmada» pone en peligro su confesión cristiana. Los términos utilizados por Figueroa son, probablemente, los más severos respecto de la minoría gitana como grupo religioso:

“¿Cómo, pues, permite la República cristiana unos malditos zánganos a quien llaman gitanos, conviniendo con ellos en el nombre sólo, que es tenebroso. Bien les cuadra el nombre, porque son vasallos del príncipe de las Tinieblas. No es demonio herege, ni infiel, aunque es caudillo de infieles y hereges. Creen los demonios y tiemblan. Que importa, pues, que los gitanos crean si en todo lo demás son demonios. Harto a peligro traen la fe en las obras, pues viven una vida desalmada... O tratan de las civias o de meleficios. Bien los llamo vasallos del demonio, porque no es otra cosa un aduar de gitanos que un execito de Satanas. Toda la república es familia al Rey, como, pues, tolera tan mala parte de familia? Y qué cuenta dará a la justicia destas almas que están por su cuenta? Malas para los próximos y peores para sí. Salen los lugares

50 Figueroa, Fray Pedro de, Aviso de Príncipes en aphorismos políticos y morales. Meditado en la historia de Saul. Madrid 1647. Madrid, Biblioteca Nacional. 
a desterrar de los campos la langosta, y consiente en sus calles la peste ${ }^{51}$.

Figueroa, evidentemente, es partidario también de expulsar a un grupo al que califica de "germanía engañosa y vagante», para lo que recurre a recordar que sobre ellos pesaba ya una orden de expulsión decretada por Carlos V. Como vemos, sin embargo, el tono de su argumentación hubiera podido tener consecuencias muy serias en el ambiente confesional de la España de los siglos XVI y XVII serán he indicado antes, pero, afortunadamente para la minoría, los demás autores se limitan a denunciar los matrimonios al margen de los grados permitidos, la inasistencia a la iglesia y el descuido de los sacramentos que nunca llegaron a provocar el celo de los inquisidores o de otras autoridades eclesiásticas. Por lo general, las acusaciones de los escritores que incluyen quejas contra los gitanos en sus libros de carácter político se refieren a la ociosidad y los perjuicios que se les atribuyen. Lo mismo que Sancho de Moncada, y los autores de principios de siglo, reclaman la expulsión de la minoría, recordando en ocasiones, que los moriscos resultaban mucho más beneficiosos al país y no pudieron escapar, sin embargo, a la medida. En este sentido se pronunciaba por ejemplo el canónigo y consultor del Santo Oficio, Pedro Fernández de Navarrete en su Conservación de Monarquías ${ }^{52}$ :

«La expulsión de los Moriscos me da motivo a tratar de la que se debiera hacer de los gitanos, tantas veces deseada, y tan mal executada; no siendo tan dificultosa la execusión, quanto dañosa la tolerancia de esta gente tan perniciosa en la república. $Y$ porque de esta materia están escritos muchos y varios papeles, en que se adelantó mucho la erudición del doctor Salazar de Mendoza...» ${ }^{53}$.

La expulsión de los moriscos, por tanto, constituía un argumento que venía a apoyar las peticiones de los memorialistas, y seguramente estuvo en el ambiente de la opinión pública durante mucho tiempo por estas fechas. Las acusaciones de holgazanería, y mala vida pesaban más en este contexto, sin duda alguna, y aunque otros autores no llegan a com-

5 FIGUEROA, fray P., Ob. cit.

${ }^{52}$ Fernández de Navarrete, Pedro, Ob. cit.

${ }^{53}$ Fernández de Navarrete, P., Ob. cit. 
parar a las dos minorías como lo hizo Fernández de Navarrete es casi seguro que la cuestión estuvo presente en el ánimo de muchos.

Después del reinado de Felipe IV ya no son frecuentes los escritores que aspiran a la expulsión de los gitanos, pero todavía se siguen dirigiendo memoriales protestando por su ociosidad, o repudiando su conducta. Éste es el sentido de las páginas que les dedica el jurista de Indias Juan Solorzano Pereyra en sus Emblemas regio-políticos ${ }^{54}$. Para Solorzano, el grupo está compuesto por "escuadras de ladrones», y sólo se trata de "unos almecenas pésimos de ociosos y hombres fraudulentos" ${ }^{55}$ que van mendigando la comida y engañando a las gentes. Solorzano recoge también la idea de que son sólo españoles degenerados, y afirma que no tienen su origen en naciones remotas, sino en la propia España, por lo que no se debe tolerar su existencia.

«No se ha de poner menos cuidado en extinguir y desterrar de nuestra república otras hezes del género humano que son los gitanos, los quales ociosos y a tropas van divagando sin aver lugar donde no hagan daño, con no parar en ninguno, ni tener oficio ni beneficio en que servir, ni saber aplicar su genio o trabajo, ni en la paz ni en la guerra» ${ }^{56}$.

En términos muy parecidos se expresa también el alcalde de Ibrillo Gabriel Pérez del Barrio, a quien ya hemos visto lamentar la presencia de extranjeros ociosos. Pérez del Barrio también acusa a los gitanos de holgazanes en su Secretario $y$ consejero de señores $y$ ministros ${ }^{57}$, y opina que no se trata de gentes cuyo origen debe buscarse fuera de España.

«Aquella república de gitanos es tan perversa que no guarda ley divina ni humana, anda repartida en tropas y cuadrillas de ladrones, embaidores, embusteros, engañadores y homicidas, haziendo y executando crueldades increibles, sus dañosas inclinaciones y mala vida piden barios discursos y menos piedad de la que con ellos se usó, yo no los tengo por gitanos, sino por hijos holgazanes de España que por viciosos, ladrones, rufianes y fulleros y otras maldades fueron castigados y afrentados por las justicias y corridos huyeron de ser conocidos y se

\footnotetext{
s4 Solorzano Pereyra, Juan, Emblemas regio-políticos. Valencia 1658.

55 Solorzano Pereyra, J., Ob. cit.

56 Solorzano Pereyra, J., Ob. cit.

57 Pérez del Barrio, Ob. cit.
} 
salen a los campos y desiertos y andan corriendo el mundo con sus amigas, robando, salteando, matando y cometiendo otros muchos y graves delitos, disfrazándose con vida gerigonças de gitanos y en cubréndose remedan la lengua» ${ }^{58}$.

Según Pérez del Barrio, concederles derecho de vecindad fue un error que les permitió seguir llevando a cabo sus robos y demás delitos, en los que muchas veces colaboran las justicias que los defienden. Los gitanos, por otra parte, «usan la treta de los lobos, que no hazen daño quatro leguas de la cama". Pérez del Barrio propone de nuevo que se les prohiba llevar a cabo compras y ventas de todo género de ganados, cabalgaduras o cualquier otra cosa, y agravando los castigos contra ellos para que se vean obligados a recogerse en los pueblos y aprender a trabajar.

Los escritos de la última parte del siglo XVII insisten en los mismos argumentos de Pérez del Barrio. Piden que se agraven los castigos, y que se hagan cumplir las pragmáticas.

Los discursos contra los gitanos se siguen escribiendo hasta finales del siglo XVII, pero después de la Pragmática de Felipe IV en que se decide que no deben ser expulsados del país, el tono utilizado por los memorialistas se modifica y orienta a subrayar los males que se originan a causa de la tolerancia de las justicias, el incumplimiento de la legislación, o por el hecho de permitirse que se acojan a la inmunidad de los lugares sagrados. Para completar el panorama de quejas impresas durante el período, todavía debemos examinar las opiniones de Pedro Villalobos, a mediados de siglo, y de un tal licenciado Franco, ya en tiempos de Carlos II.

El memorial de Pedro Villalobos se publicó en Salamanca en 1644, con el título Discursos jurídicos políticos en razón de que a los Gitanos Vandoleros de estos tiempos no les vale la lglesia para su inmunidad ${ }^{59}$. Según consta en el memorial, Villalobos era catedrático de “Vísperas de leyes» en la Universidad de Salamanca y decano de la misma, pero escribió su trabajo a instancias del corregidor de la ciudad donde ejercía como catedrático, un tal don García de Cotes Morejón y Vega, caballero del hábito de Calatrava.

${ }^{58}$ Pérez del Barrio, Ob. cit.

59 VILlalobos, Pedro de, Discurso jurídico-político en razón de que a los gitanos bandoleros de estos Reinos no les vale la Iglesia para inmunidad..., Salamanca 1644 (Madrid, Biblioteca Nacional). 
Los "discursos» de Villalobos son, en realidad, un larguísimo alegato jurídico que el catedrático presentó con el propósito de impedir la devolución a lugar sagrado de Santiago Maldonado, jefe de una compañía de 30 ó 40 hombres, al que se atribuían numerosos desmanes y algunas muertes. Maldonado era también un «conde», y en el preámbulo de la argumentación se hace la siguiente interesante descripción de la forma en que se le prestaba acatamiento por parte de su cuadrilla:

\begin{abstract}
"Qye como tal Conde de Gitanos y capitán de vandolerosse trataba y era tenido y respectado dellos, en todas las actiones que entre este género de gente podía denotar respecto y sugeción de parte de los unos y superioridad y maioria de parte del otro. $Y$ assí le servian a la messa, con gran reverencia y puntualidad, como si fuera un Conde. Quando caminava y va delante de todos en forma de Capitán, haziendoles guia y para representarlo mejor traia vanda de tal capitán, y Clarin - Trompeta, en la dicha su compañía, con que caminaba en son de guerra, y con que los llamaba cuando estaban esparcidos. Dava pasaportes o salvoconductos a los que tenía por amigos, para que los demás Gitanos no les hiziessen agravio» ${ }^{60}$.
\end{abstract}

Los hechos que se atribuían a este Maldonado eran graves y bastante numerosos. Con su compañía armada de 30 ó 40 hombres había entrado en la villa de Escurial y había derrotado a una tropa de soldados a caballo que iban a Ciudad Rodrigo. Los soldados habían acudido en socorro de los vecinos que se quejaban de las actuaciones de esta cuadrilla, pero no les fue posible controlarles. Maldonado se había apoderado, junto con sus hombres, de varios pueblos, como los Santos y el Tejado, donde hicieron "diversos escalamientos de casas, andando por los montes y caminos reales».

\begin{abstract}
«Hecho el con ellos, y todos juntos, tales ladrones famosos y salteadores públicos de caminos y de lugares cortos, despojando a los labradores, ya los caminantes de lo que tenían y llevaban, hiriéndolos y maltratandolos, y exerciendo en ellos todo género de injurias y violencias ussando de estos robos y latrocinios y cada passo".
\end{abstract}

Maldonado, al parecer, había robado a los vecinos de algunos lugares pequeños:

60 VilLalobos, P., Ob. cit. 
"cavalgaduras, alhaxas de paño y lino, trigo, tocino, pan, cocido y cebaday otras cosas sin poderlos resistir por ser muchos y la gente de este lugar poca, y sin armas, que la tienen amedrentada, yssugeta, que no les pueden yr a la mano...” ${ }^{61}$.

Al igual que en las quejas de los representantes en Cortes, la situación que evoca Villalobos es la de unos vecinos amedrentados, sin atreverse a salir de sus casas ni de hacer sus tratos por miedo a ser maltratados y robados. Maldonado al parecer actuaba siempre de cabeza visible del grupo, y en algunas ocasiones habian llevado a cabo apariciones jactanciosas:

«... Y ha visto muy pocos dias ha, que el dicho Maldonado entró en este lugar con toda su gente muy galanes, y aramados de todas las armas de fuego, y el susodicho delante, con su vanda, haziendo oficio de Capitan y caudillo ${ }^{62}$ y dezian ivan de aquella manera a una fiesta, y desta manera andan publicamente por toda la tierra temorizando los Pueblos y vezinos que no saben que hazerse, y los empobrecen $y$ aniquilan, porque les roban quanto tienen..." ${ }^{63}$.

Maldonado, por otra parte, parece que había llevado también a cabo algún asesinato, y Villalobos da cuenta de que mató a una mujer en la villa del Cubo a pesar de que estaba en el interior de una iglesia, porque le reprendió su mala vida, y en compañía de su hijo, Cazaron, mataron a otro gitano llamado Sebastián de Malla.

El alegato jurídico de Villalobos comienza aludiendo a lo dispuesto en las pragmáticas contra los gitanos, sin que aparezca en este apartado ningún elemento nuevo que añadir a la polémica. El autor se limita a señalar los daños que causan los ladrones, y especialmente los gitanos. En los siguientes apartados, el catedrático de Salamanca recuerda que la inmunidad eclesiástica no debe valer a los ladrones y, por tanto, tampoco a Santiago Maldonado, de quien vuelve a repetir se trata de un hombre peligroso que ha llevado a cabo diversos delitos.

Para ponderar mejor el peligro de los bandidos y bandoleros, Villalobos dedica todo un apartado a comparar los gitanos con los «vandole-

\footnotetext{
61 Villalobos, P., Ob. cit.

62 Subrayado en el original.

63 VIllalobos, P., Ob. cit.
} 
ros y ladrones famosos». Se trata de una digresión erudita en la que evoca ejemplos tomados de la Antigüedad clásica para volver a recordar algunos de los hechos atribuidos a Maldonado, como el ya mencionado de su asalto a la villa del Escurial y la derrota a la tropa de caballería.

A continuación, el autor pasa al punto fundamental de su disertación: «Los Gitanos son y han sido siempre sacrílegos y profanadores de Templos, y lugares sagrados. Cuéntase el modo como asisten en ellos de noche». Según Villalobos, el atrevimiento e impiedad de los gitanos es tan grande que ellos fueron quienes asaltaron a la sagrada familia cuando huían a Egipto para escapar de Herodes, ocasión en que fueron defendidos por el buen ladrón, que todavía era simplemente un niño. De este hecho fantástico Villalobos deduce su alegato fundamental:

«Con esto se dexa creer y persuadir facilmente que los que no tuvieron respecto a lesuChristo en carne humana no se lo tendrán como no se lo han tenido sacramentado, en sus Sanctos Templos, incluso en su Sagrada Custodia. Porque pruevan los testigo (Villalobos alude aquí a la profanación por parte de Maldonado y su cuadrilla de las iglesias de Carrascal y Cubo) averlos profanado estos gitanos o Vandoleros (que todo es una cosa) aposentándose en las iglesias de Carrascal, y del Cubo como si fueran ventas campestres con todo su aduar de hijuelos, y amigas (mugeres las llaman y es falso) durmiendo allí con ellas, haziendo aposento de Contubernio, y deshonestidad, el lugar de oración y pureza, entran en el juntamente, y dando de comer a sus cavalgaduras, convirtiendo en cavalleriza, y establo el Templo de Dios, en manifiesto desacato suyo, y menosprecio de sus Sanctas Imagenes, Ilenando su Sanctuario de abominaciones, que causa horror el dezirlas, y el oyrlas, y penetra, y provoca a tanta indignación a los corazones Christianos... ${ }^{64}$.

Villalobos sigue reclamando el castigo para todos los bandoleros y bandidos, el castigo más riguroso en el pesado estilo jurídico de la época, insistiendo en el hecho de que ni Maldonado ni los gitanos en general merecen la inmunidad de los lugares sagrados. Su discurso, como vemos, no contiene ninguna novedad, ni añade ningún elemento nuevo a los de Moncada, Salazar Mendoza y Quiñones, si excluimos su prolifa erudición, característica de los juristas de la época.

\footnotetext{
${ }^{64}$ VILLaLobos, P., Ob. cit.
} 
El último memorial contra los gitanos producido durante siglo XVII se redacta ya en tiempos de Carlos $1{ }^{65}$. Pertenece a un tal licenciado Antonio Franco, de quien no me ha sido posible reunir ningún otro dato. Se trata, probablemente de algún licenciado en leyes que tuvo contactos por razones profesionales con el grupo y se sintió inclinado a poner sus ideas sobre el tema por escrito.

A pesar de los años transcurridos entre los memoriales de Sancho de Moncada o Juan de Quiñones y de este anónimo licenciado, las quejas de Antonio Franco no difieren prácticamente en nada. De nuevo se alza una voz que pide la expulsión de los gitanos a pesar de que, según he señalado anteriormente Felipe IV había derogado esta amenaza durante su reinado.

Según Franco, hay dos causas fundamentales por las que no se llega a conseguir expulsarles del país. En primer lugar, a causa de la tolerancia de las justicias, que les admiten como vecinos. En segundo lugar, porque usan de la inmunidad de los lugares sagrados para su conveniencia. En el mismo farragoso estilo que Villalobos, Antonio Franco pormenoriza con abundantes citas de escritores de temas jurídicos y clásicos las razones por las que, según él, resulta perjudicial darles vecindad o permitirles que se acojan a los lugares sagrados. Respecto a la cuestión de la vecindad, el licenciado Franco es tajante:

«...los Corregidores y demás Justicias de las ciudades, villas, y lugares consienten este género de gente con el color al parecer justo de haberles admitido por vecinos y a las comunes quejas de su perjudicial compañía, satisfacen diciendo: se dio la vecindad porque SM con sus leyes reales la permitió (......), cuando esto es con las condiciones de su Real Pragmática que con su ejercicio sea el de labranza y cultura de los campos, y no tengan yeguas, armas cortas ni largas, que no asistan a ferias ni mercados, ni traten en ventas, trueques, con diferentes penas, a las Justicias que no averiguasen su modo de vivir. Pues estas vecindades, Señor, con dicha condición, es incompatible al pernicioso vivir de los gitanos ${ }^{66}$....."

Según Franco, los gitanos utilizan el derecho de vecindad concedido por Carlos II para su «licenciosa vida", de la que considera conveniente dar varios ejemplos: cinco gitanos detenidos en La Solana con caballos

\footnotetext{
65 AHN. Consejo de Ordenes Militares, libro 1332.

66 Ibidem.
} 
y bocas de fuego, cinco hombres muertos en el lugar de Barranco Hondo, y otros lugares. Según Franco, la autoría de estos hechos no deja lugar a dudas:

"Ya veo, Señor, me dirán, no se verifica que estos latrocinios y robos cometen los gitanos, que otros salteadores padecen los caminantes, mas no se queja mi bien fundada sospecha, porque estando vecinos, los campos de donde andan los gitanos, quién dudará son ellos los agresores, si se hará algún hombre muerto" ${ }^{67}$.

Como vemos, la argumentación de Franco va todavía más lejos que la de Quiñones o Salazar Mendoza, y tiene, por lo menos, la ventaja de dejar al descubierto las arbitrariedades que, sin duda, llegaron a cometerse por simples sospechas.

A pesar de que su alegato cuenta con muchas menos referencias que en el caso de sus compañeros de género, Franco se inclina por medidas radicales, y pide a Carlos II de forma bien gráfica que derogue el decreto de vecindad:

«No tenga, Señor, esta nación el labor honesto de la vecindad, sobreséase en cuanto a este privilegio y merced tantos perjuicios. Las Leyes y Pragmáticas, Señor, al tiempo que se promulgan salen justificadas, mas el estado de las cosas, como dice el Derecho, está en un continuo movimiento lo que pareció justo y cabalmente considerado, la variedad de los tiempos lo inmuta, y ya es preciso nueva providencia, quedando también la antigua justa atendiendo a aquel tiempo, que este se debe mirar en el establecimiento de las leyes, según de ellas consta. Señor, la mudanza de los tiempos, y la poca permanencia del estado de los hombres justísima causa de variar lo ya determinado por la ley...” ${ }^{68}$.

Mucho más claros y razonables parecen los argumentos que utiliza el licenciado Franco respecto al segundo punto de su memorial, la necesidad de impedir el refugio en sagrado de los gitanos. Según Franco, se trata de un auténtico fraude a la justicia:

${ }^{67} \mathrm{Ibidem}$.

${ }^{68}$ Ibidem. 
"La segunda causa que embaraza la expulsión de los gitanos es una abstracción de sagrado, que suponen pidiendo ante el eclesiástico despache sus letras contra los ministros seculares que intentan castigar sus insultos para que se les restituya a la Iglesia y la cutela suya se forma de que en los lugares disponen con los alcaldes y vecinos una riña fingida que ellos se irán de sagrado, los sacarán de él, los pondrán presos, procederán amistades o se dirán, han hecho fuga, toman su testimonio, y cuando el juez eclesiastico ofrece información, juran los vecinos, declara el alcalde lo referido, descomúlgase al juez, este resituye, vuelven a armar otro sagrado, y de esta forma siempre hay gitanos y continuas insolencias sin sacar más provecho la administración de Justicia que el que estén descomulgados sus ministros,..." ${ }^{69}$

Lo mismo que Villalobos, el licenciado Franco se lamenta de que los gitanos convierten las iglesias en "cuevas de ladrones", y se refugian en ellas a pesar de vivir observando «ritos extraviados». Después de señalar varios ejemplos de gitanos que fueron devueltos a lugar sagrado, Antonio Franco añade expresamente sus lamentaciones:

"Más, ¿qué me canso, no comen los gitanos? Claro es que comen, que son hombres, aunque rapaces, y según derecho ninguno se sustenta del aire, y $\sin$ vestirse no puede uno vivir. ¿Sirven o trabajan?. No, señor, ni heredaron de sus padres más habilidad que la que tienen, pues de dónde se sustentan, la Escritura Sagrada lo dice, pues refiere que el Santo Viejo Toribio oyó en su casa balar un cabrito, y dijo: Mirad si eshurtado.... ¿Si será milagro que los gitanos se sustentan sin tener de qué?. Bien pudiera ser que Judas era ladrón y tuvo poder de hacer milagros, como dice Atanasio, pero no se dan milagros en gentesospechosa, y que donde andan no hay dinero seguro, como siente Del Rio, y me admiro como en su libro Torreblanca (De lure Sprituali lib. 3. cap. 4) habiendo puesto un capítulo como se puede sustentar la vida sin comer ni beber, no se acordó de poner otro como se podrá comer, vestir, etc. sin tener de qué?, sino en que digamos que así como los gitanos inventaron la alquimia para de diversos polvos sacar oro, como refiere Plutarco (De Osid. et Osir. Suras in Diodo. (Julio 1. b. 5 in decretis) tienen allá algún arte para tener doblones?.. quaé doblones? caballos, capotes, galas, intersecciones de amigos, y una antedata de sagrado para que ningún Juez sea osado a poner remedio a sus licencias boem haya amén tal privilegio desdichado, pues lo mismo es no dar lugar al castigo de los delitos que constituirse reos para la pena... ${ }^{70}$.

69 Ibidem.

70 Ibidem. 
De acuerdo con los escritos que acabamos de repasar, la opinión pública del siglo XVII, tanto a través de los representantes en las Cortes como utilizando los memoriales o los escritos políticos-didacticos se manifestó con reiteración y monotonía a favor de la expulsión de la minoria gitana. Los autores son numerosos y las críticas muy severas. Según vimos al principio, se trataba en realidad de un movimiento a escala europea dirigido contra los grupos considerados poco productivos que durante el siglo XVIII tendrá consecuencias muy serias para la minoría gitana. Durante el siglo XVII, sin embargo, las medidas radicales reclamadas por las Cortes y los memorialistas no pasarán del papel, y la Corona empezará a sentirse inclinada desde mediado el siglo a tomar una actitud conciliatoria. Lejos de decretar la expulsión de los gitanos, Felipe IV decide que no resulta conveniente para el país prescindir de nuevos contingentes de la población. A partir de 1633 se puede considerar integrada a la minora gitana en nuestro país, por lo menos desde el punto de vista legal.

\section{LA INCORPORACIÓN LEGAL DE LA MINORÍA (1633)}

A pesar de los memoriales y de la abundante literatura vertida contra la minoría gitana durante el siglo XVII, la subida al trono de Felipe IV va a representar un considerable respiro, por lo menos aparente, para los hombres y mujeres de nuestro grupo. Al igual que sus antecesores, Felipe IV también dictará una pragmática acerca de los gitanos, pero después de 1633 ya no parecerá necesario expulsarles del país, por lo que se puede considerar que a partir de este momento comienza la integración de la minoría gitana en España.

Las quejas de las Cortes y los testimonios de los memorialistas no podian dejar indiferentes a los monarcas, y durante el reinado de Felipe IV (1621-1665) se inicia el proceso que va a conducir a la promulgación de un nuevo intento para controlar el problema. La futura ley se gestó lentamente. Primero se llevaron a cabo informes como el de 1628, del que hablaremos a continuación, y se tuvieron en cuenta opiniones como la que figura en un memorial dirigido al Rey por el Consejo de la Mesta, en que se proponían medidas para proteger la cría del ganado - una de las grandes preocupaciones económicas del período- a cuyo respecto se añadía la siguiente opinión: 


\begin{abstract}
«Una de las calamidades mayores que los ganaderos padecen es de los gitanos que divididos en tropas toman los ganados consumiendo para sí lo que an menester y bendiendo lo que les sobra con la mesma seguridad y livertad que si fueran propios y aunque para ocurrir a este daño se an dado comisiones generales a los alcaldes entregadores y otros ministros de Is Mesta para que cada uno pueda proceder en su distrito contra gitanos, y seguirlos fuera de el, y ordenado a todas las justicias lo excuten, no parece cesan los inconvenientes, antes los que eran particulares miran ya a lo universal de la seguridad y paz de estos Reynos, y así ha parecido consultar aparte a V. Mgd. en este punto como tan sustancial para que sobre todo provea $\mathrm{V}$. Mgd. lo que mas fuere de su real servicio " ${ }^{71}$.
\end{abstract}

Según vemos, el deseo de proteger los intereses de la Mesta fue mas poderoso que los argumentos esgrimidos por los memorialistas y las propias Cortes y esta consulta de la poderosa institución dio lugar a otro debate del Consejo en que se discutió con detalle el problema de los gitanos, puesto sobre el tapete por los ganaderos que se sentían perjudicados por algunos miembros de la minoría. En esta ocasión, como en muchas otras, la trayectoria histórica del colectivo estará determinada por esta institución que dio su impronta a tantos aspectos de la España de los siglos XVI y XVII.

La cuestión se debatió el 4 de marzo de 1633, resumiéndose las medidas que se habian tomado hasta el momento para controlar a los gitanos, añadiendo, sin embargo, que todas ellas habian sido inútiles, puesto que continúan con actos que el documento sigue calificando con dureza:

«su mal modo de vivir, y a título de nación se congregan y discurren por diferentes partes destos Reynos, invadiendo los lugares con tan gran superioridad, y pavor de los avitadores, que unos desamparan sus casas, otros tienen a buena suerte el alvergarlos, y contribuirles porque les reserven alguna parte con que sustentarse. $Y$ como las necesidades an crecido tanto se tiene por cierto se les ba agregando mucha gente facinerosa, con que si no se pone remedio promto podría este daño venir a estado que no fuese posible el dársele a costa de mucha sangre $y$ dinero" ${ }^{72}$

71 AHN, Consejos. leg. 7.33. Citado por Dominguez OrTlz, Antonio, en «Documentos sobre los gitanos españoles en el siglo XVIl», en Homenaje a Julio Caro Baroja, 1974, págs. 311 a 326.

72 AHN, Consejos, leg. 7.133. 
El Consejo propone a continuación al rey una serie de medidas que quedarán recogidas en la Pragmática de 1633, y señala claramente que no resulta oportuno expulsarles del país, a causa de la despoblación que se padece después de la salida de los moriscos. El criterio poblacionista, por tanto, impidió definitivamente la adopción de medidas drásticas, como en el caso anterior, permitiendo la incorporación legal de la minoría gitana, aunque con severas restricciones dirigidas a controlar sus movimientos. Veamos, pues, este importante documento en el que se anticipa y prepara la pragmática del mes de mayo:

"Y habiendose discurrido largamente en los medios, no a parecido conveniente el que debio de serlo en los tiempos pasados de mandar salir del Reyno los gitanos, porque la despoblazión en que se allan estos Reynos después que se expelieron los moriscos, y la que causan las necesidades presentes, no puede sufrir ninguna evacuación por ligera que sea, principalmente desta gente que no son gitanos por naturaleza ni origen sino por artificio y vallaquería, y mendados se reducirán a las costumbres y forma de vida que los demas".

"Para esto ha parecido más conveniente medio el prohivirles el trage, la lengua, y forma de vida, trato y ocupación con que se an diferenciado de los demas vecinos: que salgan dentro de un breve término de los barrios que ocupan con nombre de gitanos, y se mezclen con los demas, porque divididos no tengan caveça a quien seguir, ni se correspondan ni casen unos con otros, ni comuniquen en las torpeças, y abominaciones tan detestables como se a entendido por algunos informes de prelados, y que los que contravinieren sean castigados con penas de muerte o galeras según la calidad del hecho, o las reincidencias, que el llamar uno a otro gitano se tenga por palabra de injuria, y como tal se castigue, y que ni en dançasni en otro acto alguno se permita acción, representación, ni nombre de gitano, y las justicias atiendan con mucho recato y secreto a ver la ocupación y forma dé vida que siguen, si se comunican, o hacen algunas juntas, si se casan entre si o cumplen con las solemnidades del sacramento, si bautiçan los hijos de que se podrá tomar noticia por los curas y otras personas celosas y será muy fácil en lugares que no sean de muy gran población.»

"Que para ocurrir a las invasiones y latrocinios que hacen en los lugares y despoblados se da por ley comissión a todas las justicias así realengas como de señorio, y abadengo para que puedan proceder contra ellos, y prenderlos fuera de su distrito, yendo en su seguimiento, y la mesma jurisdicción tengan los alcaldes entregadores, y jueces de la mesta, y los demas de la comisión que la tubieren del Consejo, oasi en causas civiles como criminales para que en los caminos y lugares por donde pasaren o residieren puedan prender así infraganti como por información que estubiere hecha o noticia que se les diere de semejantes delicto, y conozcan a prevención destas causas y las entreguen a la justicia realenga más cercana del lugar donde se allaren, o que ubiere empeçado a conocer de la causa.» 
"Y que se mande a las justicias del distrito donde andubieren rovando gitanos o qualesquier otra personas, que se avisen y convoquen para que a un tiempo salgan con la gente y armas necesarias para los cercar y prender, y avisen a las justicias de los lugares por donde se puede temer su huida estén prevenidos para cogerlos con apercivimiento que se procederá con gran demostración conta la justicia que hubiere en esto omisión, y se le ará cargo en la residencia, condenándole de más de otras penas en el interés de los daños que se ubieren causado en su jurisdicción y se apliquen para los gastos desta execución todos los bienes que se allaren de los delinquentes, y los gitanos que no merecieren pena de muerte, o de galeras quedando por esclavos los que se prendieren en el campo en compañía de los susodichos, o vagando sin servir en oficio de los que no están prohividos a gitanos.»

"Y porque siendo V. M. servido de que se promulgase esta ley podría ser que muchos de los gitanos que oy están avecindados por no sugetarse a las penas della se saliesen a juntar con los que andan robando en los campos. Parece conveniente mandar que ninguno salga por tiempo de seis meses del lugar donde residiere al tiempo de su publicación pena de quedar por esclavo del que le aprehendiere al que se le aplique desde luego, y si le aprehendiere con arma de fuego sea condenado en ocho años de galeras, y se le den cien ducados al que le cogieren constando de la aprehensión por información legítima, y que en ninguna de las penas que se impusieren puedan arbitrar las justicias, $\sin$ que tengan obligación de executarlas inviolablemente. Estos es lo que se le a ofrecido al Consejo con gran deseo a acertar en punto tan importante. V. M. ordenare lo que más conviniera a su Real servicio. Madrid, y Março 4 de 1633 ${ }^{73}$.

Al margen del escrito aparece el decreto del Rey: «Como parece, con que la esclavitu se entienda en los que efectivamente lo fueren" ${ }^{74}$.

El 9 de mayo del mismo año se publicó finalmente la nueva pragmática, en la que se seguian todas las sugerencias resumidas por el Consejo en la consulta anterior. La nueva ley recoge el criterio de los Reyes Católicos al publicar las primeras disposiciones contra ellos, y se dirige a eliminar las diferencias entre los habitantes del reino. La actitud del monarca, muy lejos de las consideraciones de los antropólogos actuales, niega la originalidad étnica del grupo y procura, en consecuencia, suprimir las diferencias en traje, lengua y costumbres que puedan distinguir a los gitanos de los restantes subditos:

${ }^{73}$ AHN, Consejos, leg. 51.442, n. ${ }^{\circ} 6$. Citado por Domínguez OrTIz, art. cit.

${ }^{74}$ AHN, Consejos, leg. 51.442, n. ${ }^{\circ} 6$. 
«Que por quanto estos que se dizen Gitanos, ni lo son por origen, ni por naturaleza, sino que han tomado esta forma de vivir para tan perjudiciales efectos, como se esperimentan, y sin ningún beneficio de la República, que de aquí adelante ellos, ni otros algunos, assí hombres como mugeres, de qualquiera edad que sea, no vistan, ni anden con trage de Gitanos, ni usen la lengua ni se ocupen en los oficios que les están prohibidos, y suelen usan, ni anden en ferias, sino que hablen y vistan como los demas vezinos destos Reinos, y se ocupen en los mismos oficios y ministerios, de modo que no aya diferencia de unos a otros, pena de dozientos açotes, y seis años de galeras a los que contravinieren en qualquiera de los casos referidos; y la pena de galeras se conmute en la de destierro a las mugeres» ${ }^{75}$.

De acuerdo con este principio, según la opinión generalizada acerca de la existencia de españoles que se han fingido gitanos, los dos puntos siguientes de la ley se dirigen también a confundirles con los demás vecinos. Se les ordena salir de «los barrios en que viven con nombre de Gitanos" y que se dividan y mezclen con los demás, prohibiéndoles que lleven a cabo «juntas», tanto en público como en secreto. Las justicias están obligadas a vigilar si cumplen estas disposiciones, y si viven como cristianos, o se comunican o casan entre sí.

La Pragmática de 1633 decide en el mismo sentido "estirpar de todo punto el nombre de Gitanos», para lo que prohibe el uso del término, considerándolo como injuria grave, que se castigará de acuerdo con las penas correspondientes. Con el mismo motivo, se prohibe cualquier «accidente», «representación», «trage» o "nombre» de Gitanos bajo pena de dos años de destierro y de cincuenta mil maravedís.

Las restantes disposiciones de la pragmática de Felipe IV están dirigidas a controlar los miembros más inquietos de la minoría. A partir de seis meses después de la publicación, se prohibe a los «que oy tienen este nombre» (gitanos) que salgan de los lugares dende tienen su residencia, disponiendo que «el que fuere aprehendido por los caminos, quede por esclavo del que le cógiere", medida que recuerda las anteriores de los Reyes Católicos. En el caso de que se le encuentre con un arma de fuego, se le conducirá inmediatamente a las galeras, donde permancerá durante ocho años.

75 AHN, Alcaldes de Casa y Corte, libro 1217, fol. 228. También en la «Novísima Recopilación", tit. XVI. 
Por lo que respecta a los gitanos que andan en cuadrillas, la pragmática se preocupa de señalar que deben ser perseguidos por todas las justicias del Reino, tanto realengas, como de señorío o abadengo:

«Y porque se ha entendido que muchos Gitanos andan en quadrillas por diferentes partes del Reino, robando en despoblado, y invadiendo algunos lugares pequeños, con grave temor y peligro de los habitadores, damos por esta nuestra ley comisión general...»

También se concede derecho para detener a los gitanos a los alcaldes mayores entregadores, a los alcaldes ordinarios y a los jueces de comisión. Según vemos, se pretende que cualquier justicia del país tenga facultad para intervenir en este asunto, pero en la práctica esta medida condujo a una gran confusión y a numerosos pleitos de competencia de los que hablaré más adelante.

La Pragmática de Felipe IV, según acabamos de ver, mantiene las mismas medidas represivas contra los gitanos que andaban en despoblado 0 acuadrillados que las dictadas por los monarcas anteriores, pero aparece ya por primera vez una actitud más tolerante hacia los miembros más asimilables de la minoría, y según señalé al principio, la Corona hace desaparecer el decreto de expulsión que pesaba sobre ellos desde 1499. La Pragmática de Felipe IV es la primera en la que aparecen medidas asimilatorias, como las orientadas a hacer desparecer los barrios gitanos.

A pesar de la nueva actitud manifestada por Felipe IV, su sucesor, Carlos II, vuelve a demostrar un talante intransigente a causa de la inquietud que causan en el país las numerosas cuadrillas de bandoleros, tanto gitanos como no gitanos.

La Pragmática que emite Carlos II el 15 de junio de 1643, acerca de "La orden que se ha de tener en la prisión y castigo de los vandoleros, y gente perdida y que roban y saltean en los caminos y poblados. $Y$ el perdón que se concede a los delinquentes que los entregaren a las justicias vivos o muertos", demuestra claramente esta inquietud. Las medidas que se adoptan contra esios "vandoleros y gente perdida" son muy similaes a las que ya hemos visto en el caso de los gitanos acuadrillados, así como el tono del preámbulo de la ley. 
rentes tropas de gente perdida, que roban y saltean, executan vengaças, odios y enemistades particulares en los caminos, y se hazen sufrir en los Pueblos de poca vecindad, y aún les obligan a que les contribuyen y socorran, cometiendo graves delitos y ofensas de Dios nuestro Señor, con que perturban la quietud y reposo de nuestros vasallos, y impiden el comercio público, y que cada dia se va aumentando el número de los dichos salteadores, sin que ayan sido bastante a remediar y castigar semejantes excessos, las diligencias que han hecho nuestras justicias... ${ }^{76}$.

La preocupación de la Corona por este problema se manifiesta en el punto fundamental de esta pragmática, en el que se ordena una persecución sin cuartel ni paliativo alguno contra los llamados "vandidos públicos:

"Ordenamos y mandamos, que qualesquiera delinquentes, y salteadores que anduvieren en quadrillas robaindo por los caminos o poblados, y aviendo sido llamados por edictos pregones de tres en tres, como por caso acaecido en nuestra Corte, no parecieron ante los juezes que procedieron contra ellos a compurgarle de los delitos de que son acusados, sustanciando el processo en rebeldia, sean declarados, tenidos y reputados, como por el tenor de la presente pragmática los declaramos por rebeldes, contumaces, y vandidos públicos. $Y$ permitimos, que qualquiera persona de qualquier estado, y condición que sea pueda libremente ofenderlos, matarlos, y prenderlos sin incurrir en pena alguna, trayéndolos vivos o muertos ante los Juezes de los distritos donde fueren presos o muertos. $Y$ que pudiendo ser avidos, sean arrastrados, ahorcados y hechos cuartos, y puestos por los caminos y Lugares donde huvieren delinquido, y sus bienes sean confiscados para nuestra Camara...»

Al igual que en el caso de los gitanos, se da facultad a todas las justicias del país para perseguirles o para salir de sus distritos en su seguimiento; convocándose entre sí las justicias cercanas cuando fuera preciso, "ayudandose con gente, y otros qualesquiera medios, de manera que se consiga seguramente el efecto".

Como vemos, una actitud implacable que puede resultar sañuda desde nuestra perspectiva actual, y que se completa con otras medidas no menos rigurosas, tal como conceder el indulto a cualquier bandido que

${ }^{76}$ AHN, Consejos, leg. 51.442, núm. 6. 
«prendiere, matare o entragare» a la justicia a cualquier otro bandido. Si la persona que ejecutara lo anteriormente señalado no fuera un bandido, se le perdonarán también sus posibles delitos, con excepción de los de herejía, moneda falsa, y lesa Majestad. La pragmática concede también el indulto de dos delincuentes a aquella persona que prenda o mate a algún cabecilla, y de un delincuente tan sólo en el caso de que se trate de un bandido sin jerarquía.

Es evidente, por tanto, que Felipe IV estaba profundamente impresionado por la situación de los caminos y lugares de poca población, lo que le inclinó también a revisar el problema gitano, aunque sin consecuencia. En el mismo legajo en que se ha conservado la copia de esta pragmática aparece otra contra los gitanos de 20 de junio del año de $1643^{77}$. La nueva ley no llegó a redactarse ni promulgarse, pero la subida al trono de su sucesor Carlos II va a dar lugar a nuevas medidas sobre la minoría.

En efecto, durante el reinado de Carlos II (1665-1700) se va a producir una nueva normativa contra los gitanos. Poco antes de la mayoría de edad del monarca, el 21 de julio de 1673 -durante la privanza de D. Fernando Valenzuela - se recuerda mediante pragmática la necesidad de cumplir las leyes anteriores respecto al tema. Se limita a reproducir las disposiciones anteriores, aunque también aparece algún comentario acerca de la falta de éxito de medidas anteriores en el que merece la pena deternerse. Según se señala en esta pragmática de 1673 , no había surtido ningún efecto desterrar a las mujeres, puesto que «saliendo de estos nuestros Reinos, se pasaban a otros y en ellos se casaban o amancebaban con hombres de mal vivir como en que ellas se habían criado y a pocos días se volvían a estos nuestros Reinos, inquietándolos, introduciendo la Gitanería y jerigonza, y volviendo a experimentar con el uso de su mal vivir los mismos inconvenientes...» ${ }^{78}$.

La única disposición nueva que se toma en esta pragmática es la de enviar a los muchachos gitanos con más de diez años que anduvieran vagando a servir en las galeras, y a los menores de esta edad a las casas y "hospitales de desamparados", de acuerdo con las peticiones de las Cortes de 1623. La actitud del nuevo monarca, al igual que en el caso de sus antecesores, estuvo motivada por las frecuentes muestras de descontento y quejas que se siguieron recibiendo durante su reinado, según lo demuestra la siguierites nota de Consejo, con fecha de 8 de mayor de 1674:

\footnotetext{
7 AHN, Consejos, leg. 51.442, núm. 6.

${ }^{78}$ AHN, Consejos, libro 1474, núm. 4.
} 
"Representa el Consejo a V. M. que teniendo presentes estos y otros mas graves excessos que de ellos (los gitanos) se han experimentado, ha embiado repetidas ordenes, y las últimas al fin del año pasado de mil y seiscientos y setenta y tres a las Justicias de estos Reynos para que hagan guardar, y lo guarden inviolablemente las leyes de el Reyno, que contra esta gente están establecidas, y con augmento de penas... ${ }^{79}$.

La nota anterior del Consejo estaba compañada por un memorial de un tal don Manuel Montillo de Salas, sacerdote y abogado, acerca de los daños que originaban los gitanos en Andalucía. Según este desconocido memorialista, el incumplimiento de las leyes dictadas contras los gitanos desde los Reyes Católicos, ha causado graves daños al país, lo que es debido en gran parte a la omisión de las justicias y tribunales, puesto que desde los Reyes Católicos, ha causado graves daños al país. Lo que es debido en gran parte a la omisión de las justicias y tribunales, puesto que desde hace cuarenta no se ha ahorcado a ningún gitano. En este espacio de tiempo, señala el autor, "se an aumentado i estendido en todos estos reinos, y en particular en estas Andalucias, por ser tierra mas gruesa que pueden poblar los canpos lo que huien los poblados". Montillo de Salas sigue lamentado todavía en estas fechas el hecho de que no haya sido posible llevar a cabo la expulsión de la minoría, lo que atribuye también a la actitud de las justicias:

«Y a sido y es cosa de admirar que en ningún tiempo y en tan distintos ninguna de estas leies contra gitanos aian podido conseguir su efecto ni en mas dificultosa la expulsión de los judios y moriscos dEpaña y se consiguió con solo una zedula Real que obedecieron y cumplieron a un tiempo todas las justicias»

El tono del memorial no desdice del empleado por Quiñones o Moncada, a pesar de que la calidad literaria de su autor no está a la misma altura. Al igual que sus antecesores, Montillo les acusa de ser autores de «robos, muertes y salteamientos», y pone en duda su comportamientos religioso - «En ellos no se conoce la más mínima demostración de christiandad" - ni son útiles al país- «jamás an serbido ni sirben a $V M$. en la guerra ni en la paz, ni contribuido ni contribuyen en ningún servicio

${ }^{79}$ AHN, Consejos, leg. 51.442, núm. 6. 
real patrimonial»-. Como todos los autores que hemos visto hasta ahora, señala también que se trata de gentes «vagantes» que sólo toman asiento en «lugares muy cortos», y tampoco tienen oficio, excepto hurtar. Montilla liega a decir, incluso, que se les busca como asesinos, y que si se ocupan como herreros es para disponer de ganzúas y llaves, útiles para robar o huir de las cárceles. Montillo lamenta también que se hayan multiplicado de tal manera que su número atemoriza cada vez más a los campesinos.

«no ahy lugar que en él y en sus campos no esté poblado de gitanos que se deben de haber retirado de otras partes, y muchos lugares de corta vecindad los temen y están acobardados por cuadrillas de cincuenta y cien gitanos que se ayudan unos a otros, y muchos tienen sus caballos de frenos y espuelas $y$, carabinas dobles y arcabuces como soldados, de que usan así para sus robos como para librarse de sus riesgos".

Aunque, según veremos más adelante, esta observación del memoralista coincide con la de otros testimonios, el cálculo acerca del nùmero de gitanos que podía haber entonces en España resulta a todas luces exagerado. Según Montillo serían unos cincuenta o cien mil. Montillo termina su escrito ponderando los daños que causan al país, y a los vecinos, que están atemorizados.

"Ya los vasallos, por guardar sus vidas, se hacen amigos con ellos, y aún mujeres se incorporan y agregan y otros hombres de mal vivir, y se casan con ellos, teniendo entre si cada compañía cabeza a quien obedecer. ${ }^{80}$.

A pesar de las razones acumuladas por el sacerdote, el Consejo, que seguramente estaba habituado a recibir periódicamente quejas de este tipo, se limitó a responder que de cuando en cuando se recordaba a las justicias que debían cumplir las leyes al respecto.

Efectivamente, en el mismo legajo aparecen de nuevo papeles ponderando los males que se les atribuían. El 19 de diciembre de 1678 se discutió de nuevo en el Consejo cuáles podrían ser las medidas para

${ }^{80}$ AHN, Consejos, leg. 51.442, núm. 6. Citado por A. Dominguez OrTIz, art. cit. 
combatir los daños causados por los gitanos en los lugares de «corto vecindario", acordándose que sería conveniente que en las comarcas donde actuaban se formasen cuadrillas de hombres armados que dieran batidas en su persecución. La norma, seguramente, no llegó a ponerse en práctica, pues como señala atinadamente Domínguez Ortiz «la idea de salir en persecución de bandas armadas y acostumbradas a correterar libremente no debía seducir mucho a los pacíficos campesinos» ${ }^{81}$.

El 24 de septiembre de 1686, el Consejo volvía a lamentar los perjuicios que en el país se producían con las cuadrillas de gitanos, se señalaba que había «exceso en este número de gente», y proponía que se aumentaran las penas a las justicias omisas en estos asuntos, privándoles de sus oficios. La respuesta del Rey fue: «Como parece» ${ }^{82}$.

Al igual que en los casos anteriores, la abundancia de escritos en contra de la minoría conduce durante el reinado de Carlos II a la elaboración de una nueva pragmática con la que se pretende atajar el problema. El 20 de noviembre de $1692^{83}$ se publicaban las nuevas disposiciones. La nueva pragmática recuerda a las justicias todas las disposiciones tomadas anteriormente por la Corona, y sólo introduce la novedad de limitar los lugares donde los gitanos pueden asentarse decidiendo que no se lleve a cabo en lugares de más de mil vecinos:

«... mandamos que en ninguna ciudad, villa o lugar cuya vecindad sea de mil vecinos abaxo, asistan ni se avecinden gitanos, ni gitanas; y que los que en estos nuestros reynos se avecindaren en los que tuvieren de mil vecinos arriba, para subsistir y permanecer en ellas como los demás vecinos, se para aplicarse precisamente a la labor y cultura de las tierras, y no a otro oficio o empleo alguno".

Se les prohibía, como en todas las pragmáticas anteriores, el uso del traje y lengua, que vivan en barrios separados «sino mezclados con los vecinos de dichos lugares", o que salgan a ferias y lleven cabalgaduras mayores o menores, que en ningún caso pueden vender o trocar salvo con testimonio del escribano público en donde conste que las criaron en

81 Art. citado.

82 AHN, Consejos, leg. 51.442. núm. 6.

${ }^{83} \mathrm{AHN}$, Consejos, leg. 51.442, núm. 6. También «Novísima Recopilación», tit. 16: y Consejos, libro 1474, núm. 34. 
sus casas. Los que incumplan cualquiera de las prohibiciones anteriores quedan condenados a ocho años de galeras, "dando cuenta primero a los del nuestro Consejo, para que su orden se execute». Se ordena las justicias que visiten sus lugares de residencia para averiguar si poséen «bocas de fuego", en cuyo caso "y por el mismo hecho", se les condena también a galeras durante ocho años.

La pragmática debía publicarse en todas las ciudades, villas o lugares, que fueran cabezas de partido, para empezar a aplicarse al cabo de ocho meses de su publicación, avisándose a las justicias que vigilaran su cumplimiento y apercibiéndolas que sería cargo grave de residencia.

Como vemos, la pragmática de 1692 incluye también algunas novedades que van a dar lugar a importantes cambios en los hábitos de los miembros de la minoría. A partir de este momento, les veremos solicitar escrituras públicas para salir de sus domicilios o para hacer constar el origen de sus cabalgaduras, testimonios que podrán presentar ante los jueces de la Santa Hermandad en su defensa. El asentamiento de la minoría se va produciendo lentamente y con grandes traumas, pero de manera irreversible.

A pesar de los avances que se pueden observar en las pragmáticas de 1633 y 1692, el problema se sigue examinando con severidad durante el reinado de Carlos II, y pocos años después de la publicación de la ley que acabamos de examinar, la Corona parece arrepentirse de sus posiciones anteriores y en dos ocasiones más vuelve a ocuparse del tema en un tono más severo que en el año 1692.

El 26 de febrero de $1693^{84}$ se envía una "carta» a todas las justicias señalándoles que el Consejo ha recibido noticias de los «robos y insultos que se cometen en los caminos públicos por gitanos", y la frecuencia con que tiene lugar estos hechos. En consecuencia, se recomienda a todos los corregidores y justicias que procuren dar cumplimiento a las leyes dictadas contra ellos, no permitan en sus lugares a ningún individuo de este grupo que no esté avencidado, ni en otros oficios que los de la labranza. Es evidente que las disposiciones acerca de los lugares de vecindad, oficios etc. no se cumplían, y los gitanos se asentaban en lugares con un número inferior a 1.000 vecinos, y se ocupaban en trabajos que las pragmáticas querían prohibir. La situación debía ser tan

${ }^{84}$ AHN, Consejos, libro 1474, núm. 38. 
confusa que el 12 de junio de $1695^{85}$ se publica de nuevo otra pragmática sobre el tema. La nueva ley pretendía enfrentarse al problema del aumento del número de gitanos que había en el país a causa de la llegada de grupos de hombres y mujeres de esta minoría que procedian de Portugal y Valencia, resumiendo todas las disposiciones que se habían dictado contra ellos desde los Reyes Católicos, según consta en un documento de 7 de junio de 1695 que acompaña la copia manuscrita de la nueva ley.

"La gravedad y frecuencia de los delitos que se cometen por los Gitanos que discurren vagando por estos Reynos, cuio número es mayor aora por la persecución que han experimentado en Portugal y Valencia, ha excitado la obligación del Consejo a mirar con especial aplicación este punto, haviéndose reconocido todas las leyes y pragmáticas que en diversos tiempos desde el Reynado de los Reyes Cathólicos D. Fernando y $\mathrm{D}$. ${ }^{a}$ Isavel, hasta el de $\mathrm{V}$. Mg. se han establecido y promulgado, se han hechado menos algunas providencias que la experiencia a mostrado ser necesarias, y se ha advertido que la variedad de tantas leyes encaminadas a un mismo fin, embaraza su mejor execución, por lo qual y para las Justicias a quien toca la observancia estén más atentas a ella con la conminación de algunas penas en que incurran por sus omisiones y recivan reglas, para encaminar con mas seguridad sus operaciones; ha parecido al Consejo formar sobre esto nueva ley y pragmática en que se comprenhenda la más substancia y provechoso de las antecedentes, y se aumentan las prevenciones que se juzgan más importantes" ${ }^{86}$.

De acuerdo con el criterio adoptado por el Consejo, esta última pragmática emitida por un monarca Austria acerca de la minoría gitana, dispone que en el plazo de treinta días después de la publicación de la ley, comparezcan todos los gitanos y gitanas ante las justicias de sus lugares respectivos para declarar su nombre, edad, estado e hijos que tuvieren, así como los oficios, modos de vivir y las armas que pudieran poseer, de cualquier género y en cualquier parte donde las tuvieren. También debían declarar las caballerías que poseian, todo ellos bajo juramento y ante escribano para que se conserven estas declaraciones en el Ayuntamiento y en la Chancillería o Audiencia. El gitano que incumpliera este censo

85 AHN, Consejos, libro 1474, núm. 44 y «Novísima Recopulación», tit. XVI. También, Consejos. Colección Reales Cédulas, núm. $7 \mathrm{~A}$.

${ }^{86}$ AHN, Consejos, leg. 51.442, núm. 6. 
quedaba condenado a seis años de galeras, y a cien azotes las mujeres, y destierro, sin otro requisito para ejecutar estas condenas que haber aparecido la cosa ocultada, y presentarla a las justicias.

Una vez transcurridos los treinta días señalados para el registro se ordena de nuevo la expulsión del reino de todos los gitanos y gitanas, condenando a los que se quisieran quedar a la pena de ocho años de galeras, en el caso de los hombres, y doscientos azotes para las mujeres. La pragmática señala, sin embargo, que esta pena no debe aplicarse a los ya asimilados.

«pero esto no se entienda con los gitanos y Gitanas que se haliaren estando avencindados en Lugares cuya vecindad sea de mas de Doscientos vecinos, y no de menos, porque los tales Gitanos y Gitanas así avecindados deberán tolerarse sin pena alguna y en la forma que aqui irá declarada»" ${ }^{87}$.

Los gitanos «tolerados» no podrán tener otro «modo de vivir» que el de la labranza y cultura de los campos, donde podrán recibir la ayuda de sus mujeres e hijos, sin que se les pueda permitir que se ocupen de ningún otro trabajo, ni en tratos o comercio, que quedan prohibidos bajo amenaza de destierro y pérdida de la vecindad. Igualmente se les prohibe tener caballerías o yeguas o que puedan utilizarlas en ningún caso, bajo pena de prisión y pérdida de los animales, aunque sólo se les encuentre cabalgando en ellos. Sólo se les permite tener alguna mula o cabailería menor para acudir a la labranza o uso familiar. De la misma manera, se les prohibe tener cualquier género de armas de fuego, aunque sí se les autoriza vender las armas y caballería que tuvieran en el momento del registro.

La Pragmática prevé también un control acerca del cumplimiento de estas nuevas normas. Los corregidores y justicias tenían la obligación de visitar «por sus personas" los lugares con gitanos avecindados para vigilar sus casas y comprobar que se respetan las prohibiciones.

Continuando con las limitaciones respecto a su modo de vivir, etc, se les prohibe acudir a ferias, ni mercados, tratar en compras o ventas, habitar en barrios separados, salir de los lugares donde tuvieran su residencia, pasar a otros o vagar por los caminos, bajo severas penas. Los gitanos que fueren aprehendidos «juntos en cuadrilla» pasando de tres o con armas de fuego o a caballo, tanto si están avecindados como sino lo estuvieran incurririan en la pena de muerte, después de haberla con-

${ }^{87}$ Novísima Recopilación», tit. XVI. 
sultado con las Cancillerias o Audiencias o con el Consejo. Cuando algún gitano haya sido visto en despoblado, e incurra en la pena de muerte, podrá librarse de ella entregando a la justicia otro gitano compañero, culpable del mismo delito.

La pragmática señala también graves penas para los «receptadores» o «auxiliadores», a los que considera responsables del incumplimiento de las leyes contra el grupo, y se preocupa de señalar que deberá ser tenido como gitano, todos aquel «hombre o mujer que se aprendiere en el trabje, y habíto de que hasta ahora ha usado este género de gente, o contra quien se probare haber usado de la lengua que ellos llaman jerigonza". Al igual que en las pragmáticas anteriors, se da jurisdicción contra los gitanos infractores a todas las justicias del reino, y se les señalan puntualmente sus deberes.

El cumplimiento de la nueva pragmática parece que interesó mucho al Consejo, y el 27 de junio del mismo año, volvió a manifestar su preocupación por la cuestión. Se ordenó a las compañías de caballos que se habían formado en algunas ciudades de la costa, y a los guardias de a pie y a cabllo del resto del país que asistieran a las justicias en la persecución de los gitanos,

«sin que pueda esto ser de embarazo para que las compañías y los guardas cumplan con sus prinzipales incumbencias, pues las compañías solo tiene ocupazión ofreciendose algún rebatto, y las guardas ademas que al mismo tiempo que salieren asistiendo a las justizias pueden usar de que ttoca a su exerzixio siendo no continuas sino muy raras las ocasiones en que se nezesitará de su asistenzia no es dibersión que embaraze a lo prinzipal de su obligación.... ${ }^{88}$.

A pesar de que la pragmática de 1695 se preocupó de recopilar las disposiciones dictadas contra los gitanos desde 1499 resulta más interesante de lo que pudiera parecer a primera vista. Como hemos visto, por primera vez se intentó distinguir con claridad los gitanos asentados de los "vagantes" organizando un censo del que desgraciadamente sólo tenemos la noticia que proporciona la pragmática. La nueva ley determinaba también que los gitanos debían disponer de testimonios en los que contara el número de caballería menores de que disponían, normativa que permitirá a los gitanos aportar ante la Santa Hermandad pruebas de

${ }^{88}$ AHN, Consejos, leg. 51.442, núm. 6. 
su inocencia cuando los alcaldes entregadores pongan en tela de juicio su legalidad. Es probable que también a partir de este momento se empiecen a organizar las salidas de los lugares de residencia mediante licencias concedidas por los alcaldes correspondientes. La pragmática de 1695, por tanto, comienza a distinguir entre gitanos asentados, gitanos acuadrillados o vagabundos, lo que demuestra de alguna manera los avances conseguidos por la minoría durante las últimas centurias, y el primer paso hacia el reconocimiento por parte de la Corona de las dos realidades de la minoría. 